\title{
Demografia escrava e o impacto das leis abolicionistas no Espírito Santo (1850-1888)
}

Rafaela Domingos Lago ${ }^{1^{*}}$

\section{Resuimo}

Este trabalho consiste em um estudo demográfico do Espírito Santo entre 1850 e 1888. Nele serão consideradas as mudanças socioeconômicas, responsáveis em grande medida pelas alterações no desenho demográfico das regiões central e sul do Espírito Santo. Serão analisadas as leis referentes à escravidão que atuaram na província no sentido de libertar pouco a pouco os escravos, preservando o processo de abolição gradual orientado politicamente no Brasil e que levou, ao final, à abolição completa e irrestrita. A análise inicia-se na década de 1850, por se tratar de um período de mudanças no quadro econômico, social e demográfico do Espírito Santo. Com a emergência da cultura cafeeira, a província alcançou o maior índice de mão de obra escrava de sua história. Tal análise é fundamental para a compreensão dos anos subsequentes. Do auge da população escrava (1850-1871) passou-se à progressiva queda da mesma (18711888), quando foram analisados os impactos das leis de 1871 (Lei do Ventre Livre) e de 1885 (Lei dos Sexagenários) na demografia escrava do Espírito Santo.

\section{Palavias-chave}

Demografia escrava - abolição gradual - Espírito Santo - século XIX

'Universidade Federal do Espírito Santo, Vitória - Espírito Santo - Brasil

* Doutoranda pelo Programa de Pós-graduação em História da Universidade Federal do Espírito Santo. Bolsista da Capes. E-mail: rafaela.lago@yahoo.com.br.

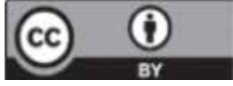




\section{Slavery demography and the impact of abolitionist laws in Espírito Santo (1850-1888)}

This work consists of a demographic study of Espírito Santo province between 1850 and 1888. In it will be considered the socioeconomic changes, responsible to a large extent for the changes in the of demographic design of the central and southern regions of Espírito Santo. The slavery laws that operated in the province in the sense of liberating slaves little by little, preserving the process of gradual abolition politically oriented in Brazil which eventually led to complete and unrestricted abolition, will be analysed. The analysis begins in the 1850 s, because it is a period of changes in the economic, social and demographic of Espírito Santo. With the emergence of the coffee culture, the province reached the highest rate of slave labor in its history. Such an analysis is criticaltounderstanding subsequentyears. Fromthepeakoftheslavepopulation(1850-1871), untiltheprogressivedecline,theimpactsofthelaws of 1871 (Law of the Free Belly) and of 1885 (Law of the Sexagenarians) in the slave demography of the Espírito Santo were analyzed.

Slave demography - gradual abolition - Espírito Santo - 19th century 


\section{Introdução}

A década de 1850 é vista por estudiosos como marco inicial da transição para o trabalho assalariado no Brasil. De acordo com a tese, a interrupção do tráfico teria causado uma insuficiência de força de trabalho para o capital cafeeiro em franca expansão. Nesse contexto, as imigrações internacionais eram vistas como fundamentais para a afirmação do mercado de trabalho capitalista.

Em obra considerada um clássico da historiografia econômica, Celso Furtado afirma que qualquer empreendimento que se pretendesse realizar após a lei antitráfico de 1850 no Brasil teria de confrontar-se com a inelasticidade da oferta de trabalho, uma vez que a população escrava brasileira teria uma taxa de mortalidade bem superior à de natalidade 1 . Diferentemente dos Estados Unidos, que possuía elevado crescimento vegetativo, para Furtado, as condições de vida dos cativos no Brasil eram extremamente precárias. ${ }^{2}$. Com a redução do abastecimento de africanos, a elevação do preço teria provocado a intensificação da mão de obra e, portanto, um desgaste ainda maior da população escrava ${ }^{3}$.

A solução para substituição do trabalho escravo, na visão de Celso Furtado, não estaria na mão de obra nacional, pois, apesar de constatar a existência de uma reserva potencial no amplo setor de subsistência, a considerava de "baixíssima produtividade"4. De igual modo isso ocorria na zona urbana onde, a despeito de acumular uma massa de população, esta dificilmente encontrava ocupação permanente. Para o economista, "as dificuldades de adaptação dessa gente e, em grau menor, daqueles que vinham da agricultura

1 FURTADO, Celso. Formação econômica do Brasil. Edição comemorativa. São Paulo: Companhia das Letras, 2009. p. 185.

2 Ibidem, p. 187.

3 Estudos realizados por Rafael Marquese, com base em manuais agrícolas que circulavam no Brasil, evidenciam, ao contrário da visão de Celso Furtado, a preocupação dos fazendeiros com o fim legal do tráfico negreiro (1831) em empreender o que consideravam um bom tratamento aos escravos. Cf.: MARQUESE, Rafael de Bivar. Senhores do corpo, missionários da mente: senhores, letrados e o controle dos escravos nas Américas, 1660-1860. São Paulo: Companhia das Letras, 2004. p. 259-298.

4 FURTADO, Celso, Op. Cit., 2009. p. 191. 
rudimentar do sistema de subsistência, contribuíram para formar a opinião de que a mão de obra livre do país não servia para a grande lavoura" ${ }^{2}$. Em consequência, segundo Furtado, mesmo na época em que a solução do problema de mão de obra parecia mais incerta, não havia evoluído no país a ideia de um amplo recrutamento interno financiado pelo governo.

Como solução alternativa, Celso Furtado destaca o fomento de uma corrente de imigração europeia na década de 1870, quando o governo imperial passou a se encarregar dos gastos do transporte dos imigrantes que deveriam servir à lavoura cafeeira. Caberia ao fazendeiro cobrir os gastos do imigrante durante o seu primeiro ano de atividade, ou seja, na etapa de maturação de seu trabalho. Também devia colocar à sua disposição terras em que pudesse cultivar os gêneros de primeira necessidade para manutenção da família. Nas palavras de Furtado, "esse conjunto de medidas tornou possível promover pela primeira vez na América uma volumosa corrente imigratória de origem europeia destinada a trabalhar em grandes plantações agrícolas" ${ }^{\prime \prime}$.

Ao discutir a mesma tese, Emília Viotti da Costa relacionou a política de mão de obra à política de terras no Brasil. A intenção dos parlamentares na criação da Lei de Terras, segundo a historiadora, era dificultar o acesso a terra pelos trabalhadores nacionais e criar condições para que o fazendeiro obtivesse mão de obra livre para substituir os escravos, cujo fornecimento estava ameaçado pela interrupção do tráfico negreiro?.

Emília Viotti da Costa observou nesse período grande oferta de mão de obra livre no Brasil. Para ela, o escravo deixou de ser a base exclusiva da economia cafeeira em regiões mais novas como São Paulo. Diferentemente de Furtado, Viotti dá ênfase à mão de obra livre nacional ao afirmar que, ao lado da corrente imigratória cada vez mais intensa às vésperas da abolição, havia crescido a participação

5 Idem, p. 191.

6 Ibidem, p. 197.

7 COSTA, EmiliaViottida. Da monarquiaà república:momentos decisivos, 5 a ed. São Paulo: Brasiliense, 1989. p. 148. 
do trabalhador livre nacional. Tanto na cidade quanto na zona rural, o trabalho livre vinha substituindo o servil, embora nesta última o fenômeno ocorresse em ritmo mais lento.

Em estudo sobre demografia, migração e transição para o trabalho assalariado no Brasil, Fausto Brito ${ }^{8}$ apoia o destaque dado por Emília Viotti aos trabalhadores nacionais. Ao analisar dados dos censos de 1872 e 1890, o pesquisador verificou que, em São Paulo, a imigração internacional ainda não se mostrava muito expressiva. No período dos censos, havia "residência de apenas 29.622 e 75.030 estrangeiros, respectivamente. Nesse último ano, seu número não ultrapassava $5 \%$ da população total".

Para Fausto Brito o financiamento da imigração internacional, mesmo com abundância de mão obra nacional, está relacionada à oferta ilimitada de terras e à organização do seu mercado. A Lei de Terras, a abolição gradual da escravidão e as migrações, interna e internacional, constituíam-se em dimensões de um mesmo processo: a transição para o trabalho assalariado no Brasil com o menor custo possível para as oligarquias, principalmente as do café. A estratégia do governo imperial nesse processo, devido à grande disponibilidade de terras, foi restringir ao máximo o acesso à propriedade, garantindo assim os interesses oligárquicos.

A imigração internacional foi contemplada na Lei de Terras de $1850^{9}$ pelas vantagens concedidas à pequena propriedade necessária à colonização, como já vinha sendo promovida pelo governo imperial mediante a constituição de colônias agrícolas. Entretanto, a imigração internacional que interessava às oligarquias na metade do século não era mais de colonos, mas sim de mão de obra livre para suprir a "falta de braços". Havia também o interesse, por parte das elites e governos, de que as migrações internacionais atendes-

8 BRITO, Fausto. Crescimento demográfico e migrações na transição para o trabalho assalariado no Brasil. Revista Brasileira de Estudos de População. Campinas, vol. 21, n. 1, p. 5-20, jan./jun. 2004. p. 9.

9 Nela, proibia-se a abertura de novas posses e restringia-se o acesso às terras devolutas, a não ser pela compra. Estas se transformaram, segundo a lei, em monopólio do Estado imperial e, mais tarde, em 1891, já na República, em monopólio dos estados, consumando assim o controle da propriedade territorial pelas oligarquias regionais (BRITO, Fausto, Op. Cit., 2004. p. 12). 
sem não só às necessidades econômicas, mas ainda a necessidades étnicas. Como destaca Thomas Skdimore ${ }^{10}$, as migrações internacionais, além de se constituírem como oferta de força de trabalho, deveriam cumprir um papel étnico de branqueamento do povo brasileiro.

Fausto Brito conclui que a intervenção do Estado no sentido de alimentar o mercado de trabalho da economia cafeeira com uma maciça imigração internacional expressava a vontade das oligarquias de uma abolição da escravatura sem atropelos econômicos e sociais, mas também a sua ideologia de construção de uma nova base étnica para a nação brasileira. $O$ papel da imigração internacional, portanto, não se restringia a suprir uma "escassez relativa de mão de obra". Foi uma estratégia do Estado e das oligarquias de tornar praticamente nulos, por meio do subsídio governamental à imigração, os custos que a abolição inevitavelmente traria para amplos setores da economia cafeeira.

Dialogando com a historiografia e tendo como fundamento a pesquisa empírica, a seguir será dado enfoque na demografia e economia de dois municípios da província do Espírito Santo, sendo um formado por pequenas propriedades e outro por extensos plantéis de escravos. Objetiva-se evidenciar a especificidade da província que, diante do fim do tráfico em 1850, ao contrário do que imaginou Celso Furtado para todo o Brasil, viu duplicar a população escrava, principalmente por meio da reprodução natural. Acredita-se, inclusive, que grande parte dos cafeicultores do Espírito Santo se encontrava segura da longevidade do sistema escravista, ou seja, pouco ou nada fez para atrair imigrantes internacionais para suas fazendas.

Com a lei de 28 de setembro de 1871 foram libertas as crianças recém-nascidas das mulheres escravas e seus senhores, obrigados a cuidar delas até a idade de oito anos. Tal lei exerceu impacto direto na fonte principal de manutenção da escravidão: o ventre das escravas. Se, em 1872, o Espírito Santo contava com cativos em quantidade nunca antes vista no local (22.659), a partir de então este índice

10 SKIDMORE, Thomas E. Preto no branco: raça e nacionalidade no pensamento brasileiro (18701930). São Paulo: Companhia das Letras, 2012. 
sofreu progressiva queda. Em dois anos, eram 362 cativos a menos. Entre 1874 e 1884, observou-se redução de 2.081. Em 1886, havia 6.835 escravos a menos na província, que passou a contar com uma população de 13.381 mancípios. Ou seja, pouco mais da metade do contingente escravo calculado em $1872^{11}$.

Para a realização do estudo demográfico da província do Espírito Santo entre 1850 e 1888 foram consideradas as especificidades locais, as mudanças sociais e econômicas atravessadas pela província e, principalmente, a vigência de leis referentes à escravidão. Pretendeu-se averiguar como a Lei do Ventre Livre (1871) e a Lei dos Sexagenários (1885) impactaram a demografia na região. Tal análise foi feita considerando o ano de 1871 como chave na desmontagem da escravidão no Brasil. Os resultados obtidos foram cotejados com pesquisas realizadas em outras regiões do Brasil. Com isso, acredita-se ter inserido o Espírito Santo no debate sobre o tema. Para tanto foi utilizado recenseamento do período em tela (1872) bem como dados populacionais dos relatórios de presidente de província (1871-1889) e registros batismais (1871-1888) da região.

\section{Do auge da população escrava}

A escravidão no Brasil persistiu até parte do último quartel do século XIX. Apesar das pressões antiescravistas, principalmente externas ${ }^{12}$, a instituição se viu fortalecida graças à emergência do cultivo do café. Segundo Robert Conrad, entre os anos de 1820 e 1830 a exportação do café brasileiro teve um aumento de quase

11 Recenseamento Geral do Império de 1872. Diretoria Geral de Estatística. Rio de Janeiro: Typ. Leuzinger/Tip. Comercial, 1876, 12 volumes. Disponível em: http://biblioteca.ibge.gov.br/; 1874, 1884 e 1887: CONRAD, Robert. Os últimos anos da escravatura no Brasil: 1850-1888, $2^{\text {a }}$ ed. Rio de Janeiro: Civilização Brasileira, 1978. p. 346, tabela 3, populações escravas, 1864-1887.

12 Foi a Inglaterra que, a partir de 1807, liderou a campanha abolicionista no século XIX, quando o tráfico transatlântico por navios britânicos e a importação de escravos novos pelas colônias britânicas foram proibidos. Cf.: MAMIGONIAN, Beatriz; SIQUEIRA, Ana Paula Pruner de. A campanha abolicionista e a escravidão no século XIX no Brasil, em Cuba e nos Estados Unidos. In: CAMPOS, Adriana Pereira; SILVA, Gilvan Ventura da (org.). A escravidão atlântica: do domínio sobre a África aos movimentos abolicionistas. Vitória: Editora GM, 2011. p. 39-72. 
$400 \%{ }^{13}$. Na década de 1850 , a produção continuou aumentando e a safra tornou-se um baluarte do sistema escravista, proporcionando meios para importação de cativos, não obstante a ilegalidade do tráfico africano de escravos após 1831.

Apesar da dificuldade em calcular com exatidão o número de africanos desembarcados nos portos brasileiros ${ }^{14}$, estima-se que depois de receber de 100 a 1.200 escravos por ano entre 1831 e 1834, o Brasil conheceu desembarques anuais de mais de 40 mil africanos em 1838 e 1839, chegando a uma média anual de quase 50 mil entre 1846 e $1850^{15}$. Tais africanos abasteciam, sobretudo, as regiões agroexportadoras. Além das regiões produtoras de café do Brasil, Cuba e Estados Unidos também passaram pelo processo de expansão escravista no século XIX.

13 O café foi introduzido no Brasil no começo do século XVIII e cultivado por toda parte com a finalidade de consumo local. Sua importância, contudo, só foi assumida no final do século, quando ocorreu a alta de preços pela desorganização do maior produtor, a colônia francesa do Haiti (FURTADO, Celso. Formação econômica do Brasil. Edição comemorativa. São Paulo: Companhia das Letras, 2009.) De 1817 a 1820, a exportação do café brasileiro alcançou uma média de 5.500 toneladas por ano e, de 1826 a 1829, a exportação anual média atingiu quase 25 mil toneladas. Cf.: CONRAD, Robert. Os últimos anos da escravatura no Brasil: 1850-1888. Rio de Janeiro: Civilização Brasileira, 1975. p. 5.

14 Segundo Manolo Florentino, nunca se saberá exatamente quantos africanos teriam desembarcado no porto do Rio de Janeiro. A falta de fontes o explica. Daí que, a partir de indicações fragmentárias, os autores que se dedicaram ao tema ora estabeleceram estimativas gerais, ora detectaram os desembarques em um pequeno número de anos. FLORENTINO, Manolo. Em costas negras: uma história do tráfico de escravos entre a África e o Rio de Janeiro: séculos XVIII e XIX. São Paulo: Companhia das Letras, 1997. p. 44)

${ }^{15}$ Cf.: BETHELL, Leslie. A abolição do tráfico de escravos no Brasil - A Grã-Bretanha, o Brasil e a questão do tráfico de escravos, 1807-1869. Rio de Janeiro: Editora Expressão e Cultura; São Paulo: Editora da Universidade de São Paulo, 1976. p. 366-373. Apud FLORENTINO, Manolo, Op. Cit., 1997. p. 43-44. Os dados elencados por Manolo Florentino sugerem que os compradores de africanos acreditavam no fim próximo e definitivo do comércio negreiro, e que tal crença se refletiu no mercado de africanos entre 1826 e 1830. Acompanhando o evolver das negociações políticas, as camadas escravistas brasileiras passaram, a partir de 1826, à compra desenfreada de africanos. FLORENTINO, Manolo, Op. Cit., 1997. p. 43-44. 
Nos Estados Unidos, a escravidão cresceu vertiginosamente entre 1783 e $1861^{16}$. Segundo Edward E. Baptist, entre a passagem da Constituição (1787) e 1860, o número de escravos expandiu em $500 \%$, principalmente por reprodução natural ${ }^{17}$. Cuba passou por crescimento semelhante. Contudo, a expansão se deu através do persistente tráfico transatlântico de escravos. De acordo com Rebecca J. Scott, a década de 1850 assistiu a um aumento no volume do tráfico ilegal de escravos em Cuba, "compensando parcialmente o decréscimo que de outro modo teria resultado das mortes e alforrias na população, cuja taxa de crescimento natural não era positi$\mathrm{va}^{\prime \prime}$.

Os Oitocentos foram, portanto, em sua maior parte, um século de expansão da escravidão que atuou em novas bases. Para diferenciar a escravidão moderna em dois momentos, Dale Tomich ${ }^{19}$ cunhou o conceito de segunda escravidão, com sua marca na virada do século XVIII para o XIX, quando um conjunto de acontecimentos e tendências ${ }^{20}$ levou a reconfigurações profundas no mercado mundial.

Nesse sentido, destaca-se o incremento do consumo de determinados produtos, como o café e o açúcar, demandados pelo

${ }^{16}$ A segunda escravidão produziu mercadorias chave para a produção industrial. Mas não apenas isso. De acordo com Edward Baptist, a segunda escravidão era culturalmente moderna e economicamente modernizante. Na expansão da escravidão dos EUA, por exemplo, a sofisticação e eficiência tecnológicas aumentavam nos campos de trabalho escravo ano após ano. Essa noção contradiz boa parte das visões de que escravistas e trabalho escravo eram estáticos. As empresas da segunda escravidão nos Estados Unidos aumentaram continuamente a produtividade do trabalho e o fizeram em níveis comparáveis aos atingidos por empresas industrializantes de tecelagem e fiação da Grã-Bretanha. BAPTIST, Edward E. A segunda escravidão e a Primeira República americana. Almanack. Guarulhos, n. 05, p. 5-41, 1º semestre de 2013.

17 Ibidem, p. 10.

18 Segundo Scott, as cifras dos registros de escravos apresentam para 1855-1857 um total em torno de 373.000 escravos. Cf.: SCOTT, Rebecca J. Emancipação escrava em Cuba: a transição para o trabalho livre, 1860-1899. Rio de Janeiro: Paz e Terra; Campinas: Unicamp, 1991. p. 28-29.

19 TOMICH, Dale W. Pelo prisma da escravidão: trabalho, capital e economia mundial. São Paulo: Edusp, 2011.

${ }^{20}$ Principalmente o advento da Revolução Industrial na Inglaterra e a hegemonia internacional da Grã-Bretanha. 
aumento da população de trabalhadores e da classe média nas cidades da Inglaterra e da Europa e a procura por novas matérias-primas como o algodão. Tal conjunto de transformações afetou determinadas áreas coloniais escravistas, implicando seu declínio, mas atuou sobre outras áreas escravistas em sentido inverso. Em regiões como Cuba, o Sul dos Estados Unidos e o Brasil, a escravidão "expandiu-se numa escala maciça para atender à crescente demanda mundial de açúcar, café e algodão"21.

Nesse contexto de integração da escravidão com o desenvolvimento do capitalismo industrial e do mercado mundial do século XIX, o Império do Brasil e, em específico, uma de suas províncias, teve o cenário econômico-social e desenho demográfico transformados.

Refiro-me à província do Espírito Santo e às mudanças observadas a partir de 1850 na região que afetaram significativamente as décadas seguintes. Até meados dos Oitocentos, o Espírito Santo teve a sua economia baseada na cultura canavieira, de longa tradição colonial ${ }^{22}$. A província era composta majoritariamente de pequenas propriedades voltadas para a produção de alimentos para abastecimento do mercado interno. A partir de então, o Espírito Santo, assim como outras províncias do Império ${ }^{23}$, se viu atraído pelo café, estimulado pela crescente demanda do produto em países europeus, como visto anteriormente ${ }^{24}$.

21 TOMICH, Dale W., Op. Cit., 2011 . p. 83.

22 Sobre a economia colonial do Espírito Santo, conferir: CARVALHO, Enaile Flauzina. Redes mercantis: a participação do Espírito Santo no complexo econômico colonial de 1790-1821. Vitória: Secult, 2010. CONDE, Bruno Santos. Depois dos jesuítas: a economia colonial do Espírito Santo (1750-1800). Dissertação (Mestrado em História). Universidade Federal do Espírito Santo, 2011.

23 Refiro-me às regiões de plantations das províncias do Rio de Janeiro, São Paulo e Minas Gerais.

24 Basílio de Carvalho Daemon relata que, em 1815, foram remetidos a diversos lavradores do norte da capitania as primeiras sementes de cafeeiro, recomendando-se seu plantio e cultura. DAEMON, Basílio Carvalho. Província do Espírito Santo: sua descoberta, história cronológica, sinopse e estatística (1879). Vitória: Secretaria do Estado da Cultura; Arquivo Público do Estado do Espírito Santo, 2010. p. 282. 
Segundo Gabriel Bittencourt ${ }^{25}$, é difícil reconstituir os primeiros passos da cafeicultura no Espírito Santo. Sabe-se que já existia em pequena escala em 1811. Contudo, não devia ser considerável. Com reduzido número de habitantes nessa época, o Espírito Santo conservava sua exuberante floresta tropical que atingia aproximadamente $90 \%$ de seu atual território. Em fins da década de 1820, havia aproximadamente 24 mil habitantes em terras capixabas, concentrada apenas no litoral e daí para o interior até no máximo quatro léguas.

O desenvolvimento da cafeicultura no Espírito Santo influenciou paulatinamente o desbravamento da floresta, a imigração europeia não portuguesa e fixação dessa mão de obra e, principalmente, a construção de estradas de rodagem, a navegação a vapor e, até mesmo, a ferrovia. O café será, portanto, a mola mestra do reaparelhamento material do Espírito Santo ${ }^{26}$.

Já em 1854, o café já constituía a principal renda da província ${ }^{27}$. A partir dessa data, a produção cafeeira não cessava de crescer e, em grande parte da região, sua cultura foi invadindo o solo, ocupando espaços, absorvendo recursos financeiros e mão de obra anteriormente empregados em outras áreas e culturas, principalmente na de cana de açúcar.

A atividade cafeeira, contudo, ocupou de maneira desigual as diversas áreas da província. Na região sul, nos vales do Itapemirim e Itabapoana, o processo foi mais agressivo. Segundo Gabriel Bittencourt ${ }^{28}$, à proporção que as melhores terras fluminenses iam se tornando domínio dos grandes senhores, a "franja" do café para o norte ia invadindo o Espírito Santo.

A maior atração, em relação às demais regiões da província, se deveu, em grande medida, às imensas áreas que ainda não haviam

\footnotetext{
${ }^{25}$ BITTENCOURT, Gabriel Augusto de Mello. Café e modernização: o Espírito Santo no século XIX. Rio de Janeiro: Liv. Ed. Cátedra, 1987. p. 21-22.

${ }^{26}$ Ibidem, p. 27.

${ }^{27}$ ALMADA, Vilma Paraíso Ferreira de. Escravismo e transição: o Espírito Santo. 1850/1888. Rio de Janeiro: Edições Graal, 1984. p. 61.

${ }^{28}$ BITTENCOURT, Gabriel Augusto de Mello, Op. Cit., 1987. p. 27.
} 
sido apropriadas na região sul. Esses espaços foram desbravados sobretudo por fazendeiros fluminenses e mineiros que vinham com seus escravos e com recursos próprios, estabelecendo importantes fazendas na região ${ }^{29}$. Também merecem destaque as condições naturais mais favoráveis ${ }^{30}$ no sul que no restante da província - sobretudo no que diz respeito ao solo massapê, consistente e resistente à erosão. O café, portanto, substituiu a antiga cultura e atuou como um poderoso atrativo econômico no processo de ocupação das matas virgens no interior dessa região ${ }^{31}$.

A rápida ocupação cafeeira refletiu-se nas transformações administrativas dessa parte do Espírito Santo. Segundo relatório de presidente de província, o município de Itapemirim era composto em 1856 por Itapemirim, Cachoeiro e Itabapoana. No mesmo ano, Cachoeiro foi elevada de vila a freguesia. Em 1867, foi instalado o município de São Pedro de Cachoeiro ${ }^{32}$. Em 1872, Cachoeiro já tinha sob sua jurisdição diversas freguesias ${ }^{33}$.

No município de Vitória ${ }^{34}$, região central, ocorreu a substituição da cultura canavieira e o avanço da atividade cafeeira entre 1852

29 Entre os desbravadores, destaca-se o futuro barão de Itapemirim, paulista; o mineiro Manoel Esteves Lima (português no nascimento e fazendeiro em Minas Gerais); o mineiro Francisco de Souza Monteiro e outros tantos mineiros e fluminenses pobres que também foram atraídos pelas terras devolutas da nova região do café (SALETTO, Nara. Transição para o trabalho livre e pequena propriedade no Espírito Santo (1888-1930). Vitória: Edufes, 1996. p. 29-30).

30 De acordo com Nara Saletto, na região sul, além do solo propício, o clima era úmido e apresentava chuvas mais regulares que as observadas em algumas áreas do centro, sujeitas à seca (SALETTO, Nara, Op. Cit., 1996. p. 35).

31 Sobre a ocupação da região sul, conferir o primeiro capítulo do livro: SIMONATO, Juliana Sabino. Fazenda Santa Helena: escravidão, bastardia e poder. Vitória: IHGES, 2013.

32 O município de São Pedro de Cachoeiro foi instalado em 25 de março de 1867 pelo presidente da Câmara Municipal de Itapemirim, tenente Joaquim José Gomes da Silva Neto. Cf. DAEMON, Basílio Carvalho, Op. Cit., 2010. p. 435.

${ }^{33}$ As freguesias são: São Pedro de Alcântara do Rio Pardo, São Miguel do Veado, São Pedro de Itabapoana, São José do Calçado, Nossa Senhora da Conceição do Aldeamento Afonsino e Nossa Senhora da Penha do Alegre. Já o município de Itapemirim constituía a freguesia de Nossa Senhora do Amparo de Itapemirim. Cf.: Recenseamento Geral do Império, 1872.

${ }^{34}$ O município de Vitória era composto pelas freguesias Nossa Senhora da Vitória, São José do Queimado, São João de Cariacica, São João de Carapina e Santa Leopoldina (Recenseamento Geral do Império, 1872). 
e 1873. De acordo com Nara Saletto, o cultivo do café em Vitória começou na zona antiga, em seus arredores. A expansão se fez, principalmente, pelo deslocamento de recursos até então aplicados no açúcar, no algodão e em culturas de subsistência. Diferentemente da região sul, Vitória não era uma zona pioneira de desbravamento e imigração 35 . Além disso, segundo Vilma Almada, a produção na região central era modesta e em pequenas lavouras, pois dividia espaço com a produção de alimentos para abastecimento do mercado interno ${ }^{36}$.

As regiões do norte foram as menos influenciadas pelo café nessa época. São Mateus ${ }^{37}$ permaneceu com sua tradicional produção de farinha de mandioca, Santa Cruz, Nova Almeida e Linhares dedicavam-se quase exclusivamente à extração de madeira ${ }^{38}$.

Apesar das dificuldades impostas pelo fim do tráfico em 1850, a produção de café revitalizou e ampliou a instituição escravista, assegurando o papel de pilar da economia capixaba até $1888^{39}$. A atividade cafeeira também foi a responsável pelo crescimento populacional da província que, no período de 1856 a 1872, viu expressivo crescimento da população livre e praticamente duplicada sua população escrava (gráfico 1).

\footnotetext{
${ }^{35}$ SALETTO, Nara, Op. Cit., 1996. p. 46.

${ }^{36}$ ALMADA, Vilma Paraíso Ferreira de, Op. Cit., 1984. p. 64.

37 Segundo Bittencourt, apesar de São Mateus possuir 55 fazendas, produzindo cerca de 30.000 arrobas anuais de café, era o sul que apresentava as melhores perspectivas. BITTENCOURT, Gabriel Augusto de Mello, Op. Cit., 1987. p. 28.

${ }^{38}$ ALMADA, Vilma Paraíso Ferreira de, Op. Cit., 1984. p. 64.

39 Ibidem, p. 12.
} 


\section{Gráfico 1}

\section{Crescimento populacional de livres e escravos} da província do Espírito Santo (1856 e 1872)

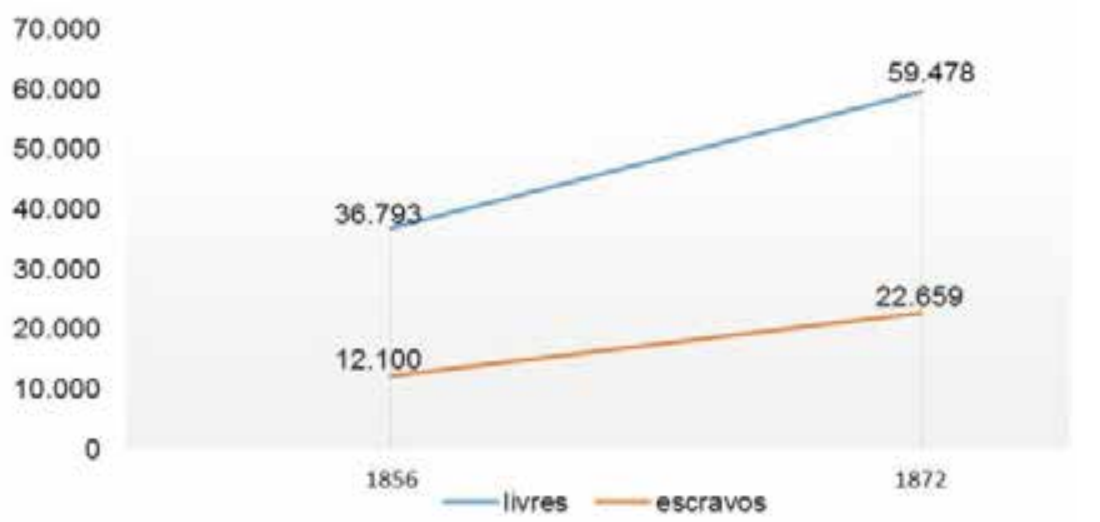

Fontes: Relatório com que o exm. snr. presidente da província do Espírito Santo, o doutor José Mauricio Fernandes Pereira de Barros, passou a administração da província ao exm. snr. commendador, José Francisco de Andrade e Almeida Monjardim, segundo vice-presidente, no dia 13 de fevereiro de 1857; Recenseamento Geral do Império, 1872. Diretoria Geral de Estatística. Rio de Janeiro: Typ. Leuzinger/ Tip. Commercial, 1876. Dados sobre o Espírito Santo. Disponível em: www.cebrap.org.br/recensemaento/01/index.html.

Em 1856, a província do Espírito Santo possuía 48.893 habitantes. Passados dezesseis anos, a população aumentou para $82.137^{40}$. Enquanto o número de livres subiu de 36.793 para 59.478, o de escravos saltou de 12.100 para 22.659. Ao passo que a participação da população livre diminuiu de $75,2 \%$ para $72,4 \%$, a escrava elevou-se de $24,8 \%$ para $27,6 \%$ entre 1856 e 1872 .

${ }^{40}$ Segundo o censo de 1872, a província do Espírito Santo possuía pouco menos de um por cento $(0,8 \%)$ dos habitantes do Brasil (10.112.061). As províncias do Rio de Janeiro e São Paulo contavam com $8 \%$ cada, e Minas Gerais com $20,8 \%$ da população total do Império. 
O recenseamento de 1872 registrou no Espírito Santo a segunda maior proporção de escravos entre as províncias do Brasil: 2,6 livres por escravo. Ela foi superada apenas pela do Rio de Janeiro, com 1,6 livres por cativo. Em São Paulo eram 4,3 e em Minas Gerais 4,541.

No gráfico 2, é possível visualizar o crescimento da população escrava do Espírito Santo, com especial atenção para partes das regiões central e sul, nas quais o trabalho se concentrará devido a significativa presença de cativos em relação às outras regiões da província.
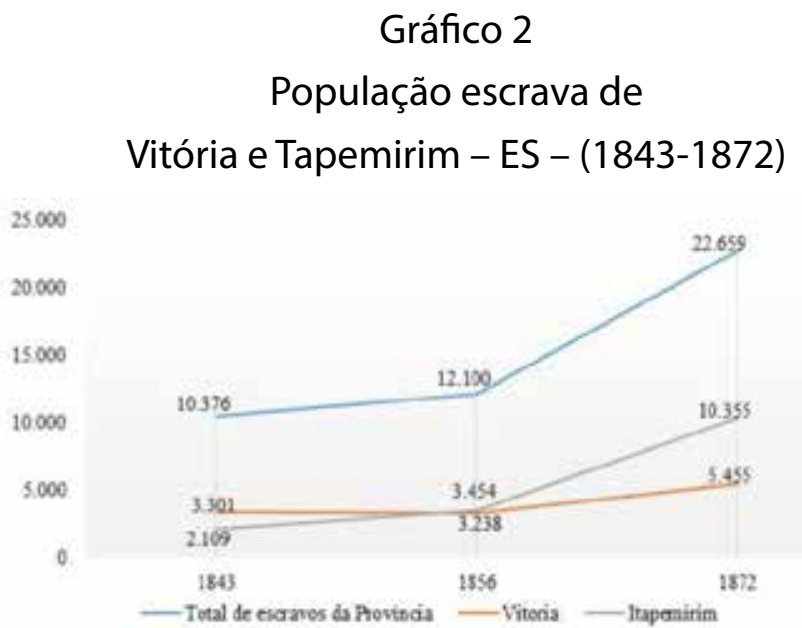

*Os 10.355 escravos se referem à região de Itapemirim composta pelos municípios de Cachoeiro de Itapemirim (com 7.482 cativos) e de Itapemirim (com 2.873 cativos).

**Os 5.455 escravos se referem aos municípios de Vjtória (com 3.678 escravos), Viana (com

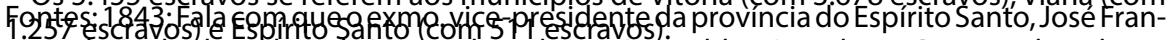
cisco de Andrade e Almeida Monjardim, abriu a Assembleia Legislativa Provincial no dia 23 de maio de 1844. Rio de Janeiro: Typ. Imp. e Const. de J. Villeneuve e Comp., 1845. 1856: Relatório com que o exmo. sr. presidente da província do Espírito Santo, o doutor José Mauricio Fernandes Pereira de Barros, passou a administração da província ao exmo. sr. comendador, José Francisco de Andrade e Almeida Monjardim, segundo vice-presidente, no dia 13 de fevereiro de 1857. Brasil: Diretoria Geral de Estatística - Censo de 1872.

${ }^{41}$ Em 1872, havia no Rio de Janeiro 490.087 livres e 292.637 escravos. Em São Paulo, 680.742 livres e 156.612 escravos. Em Minas Gerais, 1.689.276 livres e 376.459 escravos (Recenseamento Geral do Império, 1872). 
Para maior compreensão das mudanças na demografia escrava da região foram inseridos no gráfico dados da primeira metade do século XIX. Em 1843, havia 10.376 escravos na província, dos quais $32 \%$ (3.301) se concentravam em Vitória. No mesmo ano, Itapemirim contava com $20 \%$ (2.109) do total de escravos. Juntos computavam no período mais da metade (52\%) dos cativos de toda a província. Em 1856, Itapemirim ultrapassou a marca de mancípios de Vitória, passando para 28,5\% (3.454), e Vitória figurou com 26,7\% (3.238). Ambos representavam $55,2 \%$ da população escrava do Espírito Santo.

Em 1872, graças ao crescimento vertiginoso de cativos, Cachoeiro de Itapemirim e Itapemirim passaram a contar com pouco menos da metade da população cativa de toda a província (45,7\%). Vitória, nesse ínterim, contabilizou praticamente metade do número de escravos de Itapemirim e pouco menos de um quarto (24\%) dos escravos da província. O ano de 1872 marcou, portanto, a definitiva inversão da primazia populacional de escravos da região central para o sul do Espírito Santo.

Deve-se destacar também a alta proporção de africanos. O Espírito Santo, conforme o recenseamento de 1872, possuía, entre todas as províncias, o segundo maior percentual de africanos na população escrava, $10 \%{ }^{42}$, superado apenas pelo Rio de Janeiro, com $19,2 \%{ }^{43}$. No município de Cachoeiro de Itapemirim essa taxa era ainda mais elevada que no conjunto da província, chegando a 17,4\%, pois ele concentrava $57,7 \%$ dos africanos nele existentes ${ }^{44}$.

A região sul tornou-se importante polo de atração de mão de obra escrava com o crescimento da produção cafeeira. Em 1876, chegou a representar $57 \%$ da população cativa da província. Tal fenômeno também foi observado em outras áreas do Brasil. Segun-

\footnotetext{
42 Em 1872, havia no Espírito Santo 20.397 escravos brasileiros e 2.262 africanos.

43 Em 1872, havia no Rio de Janeiro 292.637 escravos, dos quais 236.375 eram brasileiros e 56.262 africanos.

${ }^{44}$ Em 1872, havia no município de Cachoeiro de Itapemirim 6.177 escravos brasileirose 1.305 africanos.
} 
do Carlos Hansenbalg ${ }^{45}$, durante as três décadas seguintes a 1850 , ocorreu um intenso processo de migração escrava inter-regional das áreas menos lucrativas para a região cafeeira, como solução parcial e temporária para atender a ascendente demanda de trabalho.

A importância do trabalho escravo é melhor compreendida quando observamos o caráter agrícola da província do Espírito Santo. Em 1872, contava com uma população de 31.671 lavradores, ou seja, $56,6 \%$ das 55.950 pessoas que possuíam uma profissão ${ }^{46}$. Nesse contexto, observamos que, apesar de todos os obstáculos impostos à escravidão, como o fim do tráfico negreiro, $40,8 \%$ da força de trabalho agrícola, que consistia em 12.917 escravos, se dividia pelas diversas regiões da província, seguindo principalmente os ritmos da lavoura cafeeira. Segundo Vilma Almada ${ }^{47}, 64,2 \%$ concentravam-se na região de Itapemirim e 18,5\% na região da capital. Dos restantes, $14,7 \%$ viviam em São Matheus engajados no plantio de mandioca, enquanto apenas 2,5\% viviam na região de Reys Magos, por predominar ali o trabalho livre na extração de madeira.

Segundo Adriana Campos, a elite no Brasil estava atada ao compromisso de manutenção da escravidão ${ }^{48}$. Tal afirmativa é perfeitamente cabível à região sul da província, como prova a preponderância da mão de obra escrava nessa região. Mesmo diante de leis antiescravistas, os fazendeiros produtores de café do sul se mostravam confiantes em relação à manutenção do trabalho escravo em seus cafeeiros.

OVale do Paraíba fluminense é uma região do Sudeste exemplar da hipótese acima. Segundo Robert Slenes ${ }^{49}$, no início da década de $1870,93 \%$ da força de trabalho que labutava no café eram de ca-

45 HASENBALG, Carlos Alfredo. Discriminação e desigualdades raciais no Brasil. Rio de Janeiro: Graal, 1979. p. 143.

${ }^{46}$ De acordo com o censo de 1872, dos 82.137 habitantes da província, 55.950 possuíam uma profissão e 26.187 foram registrados como sem profissão.

${ }^{47}$ ALMADA, Vilma Paraíso Ferreira de, Op. Cit., 1984. p. 120

${ }^{48}$ CAMPOS, Adriana Pereira. Nas barras dos tribunais: Direito e escravidão no Espírito Santo do século XIX. Programa de Pós-graduação stricto sensu em História da UFRJ, 2003. p. 60.

49 SLENES, Robert. Senhores e subalternos no oeste paulista. In: ALENCASTRO, Luiz Felipe de. História da vida privada. São Paulo: Companhia das Letras, 1997. vol. 2, p. 233-290, p. 243. 
tivos. Já nos principais municípios do oeste paulista voltados para esse produto apenas $27 \%$ dos escravos se dedicavam ao seu cultivo. Entretanto, nos anos de 1880, o grau de especialização monocultora no escravismo do oeste paulista atingiu o mesmo nível que o do Vale do Paraíba fluminense, graças ao recrudescimento do comércio interno de escravos nos anos 1870. Nas palavras de Slenes, quando o café se tornou a força motriz da economia no oeste paulista, foram despejados milhares de cativos na região vindos, sobretudo, do Nordeste e do Rio Grande do Sul ${ }^{50}$.

Os dados referentes ao Espírito Santo não significam, no entanto, que a região de Vitória, menos próspera que a região de Itapemirim, havia aberto um largo espaço ao trabalho livre. Devemos considerar suas diversas regiões. Dentre os 268 lavradores da paróquia de Vitória em 1872, por exemplo, $218(81,3 \%)$ eram escravos e 50 $(18,6 \%)$ livres. Em Viana, dos 925 lavradores, $584(63,1 \%)$ eram cativos e $341(36,9 \%)$ eram livres. Outras paróquias como Serra, Espírito Santo e Carapina também utilizavam consideravelmente a mão de obra escrava na agricultura, variando entre $31 \%$ e $48 \%$ sua participação. Já as paróquias de Cariacica, Queimado e principalmente as colônias de imigrantes de Santa Leopoldina e Santa Isabel ${ }^{51}$ possuíam a maioria de seus lavradores livres: eram 679 (85,8\%), 551 (75,8\%), 449 (78\%) e 1.080 (99\%), respectivamente ${ }^{52}$.

Sabe-se por meio de pesquisas realizadas por Vilma Almada que não houve um importante tráfico intraprovincial no Espírito Santo ${ }^{53}$. Ao analisar escrituras de venda de escravos do município de Vitória nos anos de 1871 a 1877, a historiadora não constatou significativo número de vendas para o município de Cachoeiro de Itapemirim $^{54}$.

50 Entre 1779 e 1829, a população escrava no município cresceu de 156 para quase 4.800. Em 1872, ela atingiria 14 mil. SLENES, Robert, Op. Cit., 1997. p. 249.

51 Os núcleos coloniais de imigrantes europeus foram criados pelo governo imperial a partir de 1847: a colônia de Santa Leopoldina em 1856 e a de Santa Isabel em 1847. Ambas produziam principalmente café e cereais.

52 SALETTO, Nara, Op. Cit., 1996. p. 76.

53 ALMADA, Vilma Paraíso Ferreira de, Op. Cit., 1984. p. 117.

54 De acordo com Almada, em 80 escrituras, totalizando 91 escravos, 76 (83,5\%) permaneceram na região da capital, 13 (14,3\%) foram para outras províncias e apenas dois (2,2\%) dirigiram-se 
Utilizando-se da estatística de 1875 de uma freguesia deste município $^{55}$, Almada destacou que 443 escravos (38,1\% do total) eram oriundos da região Centro-Sul, sendo que, desses, 296 (66,8\%) eram naturais de Minas Gerais, 142 (32\%) do Rio de Janeiro e cinco $(1,2 \%)$ de São Paulo. Os demais 282 ( $24,2 \%$ do total) eram africanos, 77 $(6,6 \%)$ do Norte-Nordeste e apenas $362(31,1 \%)$ tinham nascido no Espírito Santo.

Ao explorar os inventários do município de Cachoeiro entre 1874 e 1886, a pesquisadora confirmou a veracidade dos dados. Dos 279 escravos pesquisados, 111, ou seja, 39,8\%, haviam nascido no Espírito Santo, enquanto os restantes $168(60,2 \%)$ eram naturais de Minas Gerais. Os demais 44 escravos $(15,8 \%)$ eram africanos ou naturais de outras províncias ${ }^{56}$. Almada concluiu, portanto, que um grande número de escravos chegou ao município de Cachoeiro acompanhando seus senhores, quando estes emigravam das províncias vizinhas em busca de terras onde pudessem abrir novas fazendas.

Havia também aqueles africanos que não chegaram à região sul espiritossantense acompanhados por seus proprietários. Documentos oficiais como relatórios de secretários de Estado e de chefes de Polícia, revelam a resistência ${ }^{57}$ da província ao cumprimento da lei de 4 de setembro de $1850^{58}$. Neles foram localizados ofícios sobre contrabando de africanos até $1856^{59}$.

para o município de Cachoeiro.

55 Vilma Almada optou por usar os dados estatísticos de 1875 da população de Nossa Senhora da Penha do Alegre por crer na displicência daqueles que responderam ao Censo de 1872 no que se refere à origem dos escravos do município de Cachoeiro. ALMADA, Vilma Paraíso Ferreira de, Op. Cit., 1984, p. 117.

56 Ibidem, p. 117-118.

57 Ositehttp://www.slavevoyages.orginformaque8.812africanos desembarcaramnoBrasilentre 1851 e 1866. Contudo, énecessário destacar que, se comparado comanos anteriores (1826-1850) em que desembarcaram 1.236.577 africanosem costas brasileiras, aquelenúmerosetornamenosexpressivo.

58 A referida Lei n 581 estabeleceu medidas para a repressão do tráfico de africanos no Império. Conferir na íntegra em: http://www.planalto.gov.br/ccivil_03/Leis/LIM/LIM581.htm.

591850 marcou a crise da mão de obra no Império desencadeada pela abolição da fonte externa de abastecimento do mercado de escravos. Os senhores brasileiros, entretanto, anteciparam-se à proibição definitiva e "demonstrando grande capacidade de arregimentação de recursos (...) passaram à compra desenfreada de africanos". FLORENTINO, Manolo, Op. Cit., 1997. p. 47-48. 
Dentre os documentos merecem destaque para o presente trabalho aqueles que indicam a quantidade de africanos envolvidos. Foi o caso da denúncia feita pelo Ministério de Justiça da Corte ao presidente da província e remetido aos delegados de Itapemirim e Guarapari, além dos subdelegados de Benevente ${ }^{60}$, sobre o desembarque de 170 africanos "boçaes" feito pelo negociante Joaquim Ferreira de Oliveira com a ajuda de seus sócios Joaquim da Fonseca Guimarães e Geraldo ${ }^{61}$, responsáveis por conduzir os africanos para o interior de Itapemirim.

Em outro documento, referente a 1851, consta ter o chefe de Polícia, José Bonifácio, recebido oficio reservado do chefe de Polícia da Corte, que se prontificava em enviar sua força policial para a vila de Itapemirim a fim de auxiliar o delegado na diligência. Fora denunciado o "desembarque em Itapemirim de 270 africanos na fazenda do coronel João Gomes, cunhado, que se diz do barão de Itapemirim"62.

O desembarque de outros 100 africanos foi informado ao chefe de Polícia da vila de Itapemirim. Tal carregamento pertencia ao negociante Jose Bernardino ${ }^{63}$. Outro oficio ${ }^{64}$ enviado pela Corte ao chefe de Polícia Felipe Jose Pereira Leal e posteriormente pelo secretário de Guerra, Jose Augusto Cesar Nabuco de Araujo, comunicava o desembarque de aproximadamente 120 africanos que vieram da costa da África em um palhabote de propriedade de Antônio Pinto da Fonseca. O chefe de Polícia informou que o desembarque seria realizado entre os pontos de Itabapuama e Piúma e que se esperava um navio negreiro na fazenda chamada Sens, vizinha ao rio Itapemirim, onde já estava um caixeiro de José Bernardino de Sá, de nome Mendes e um tal de Oliveira, aguardando um patacho.

\footnotetext{
60 Apees. Ofício enviado aos delegados de Itapemirim e Guarapari e subdelegados de Benevente. 1851. Série Accioli, livro 66 (manuscritos).

61 O documento não informa o sobrenome de Geraldo.

62 Apees. Oficio com denúncias dirigidas ao chefe de Polícia. 1851. Série Accioli, livro66 (manuscritos).

63 Idem.

${ }^{64}$ Idem.
} 
Por fim, passados seis anos da publicação da Lei Eusébio de Queirós, registrou-se o precatório de prisão contra Jose Alz da Costa, negociador e irmão de Manoel Alves da Costa Bastos, que veio da África na escuna Mary e Smitte, apreendida em 20 de janeiro na barra de São Matheus, onde estava fundeada com 384 africanos "boçaes", importados "contra o disposto nas leis de sete de novembro de 1831 , quatro de setembro de 1850, e cinco de junho de 1854"65.

Pelo menos até 1856, era fato reconhecido o desembarque de centenas de africanos nas praias do Espírito Santo. Ainda que boa parte dos africanos fosse encaminhada aos cafezais do Sudeste brasileiro, especialmente aqueles localizados nas prósperas fazendas do Rio de Janeiro e São Paulo, grandes fazendeiros, principalmente da região sul do Espírito Santo, praticaram o comércio ilícito com intuito de abastecer de mão de obra africana suas escravarias.

A recorrência ao tráfico intraprovincial não fora significativa para o abastecimento de mão de obra no reduto cafeeiro da província. A região exerceu atração de fazendeiros acompanhados de seus escravos provenientes principalmente de Minas Gerais e Rio de Janeiro, áreas próximas da província, a fim de se estabelecerem nos sertões com seus escravos ${ }^{66}$. Houve também, nos anos seguintes à Lei Eusébio de Queirós, tentativas de desembarque ilegal de africanos na região. Contudo, a manutenção do escravismo, tanto nessa região como no centro da província, resguardadas as diferenças, ocorreu principalmente pela via da reprodução natural.

A região central da província era composta majoritariamente de pequenas propriedades dedicadas ao abastecimento do mercado interno, nas quais o cultivo do café dividia espaço com diversos gêneros de subsistência. Ao analisar inventários post-mortem entre 1850 e 1871, Patrícia Merlo observou que a posse de escravos em

65 Apees. Precatório de prisão. Ofício do juiz da Auditoria da Marinha da província da Bahia contra José Alz da Costa. Série Accioli, livro 66 (manuscritos).

66 Para essa região não foram atraídos apenas fazendeiros dotados e recursos. Segundo Nara Saletto, também migraram mineiros e fluminenses pobres, além de habitantes de outras áreas do Espírito Santo. Esses habitantes formaram a povoação de Rio Pardo e estavam um pouco por toda parte. SALETTO, Nara, Op. Cit., 1996. p. 30-31. 
Vitória era distribuída em diversos setores da sociedade local, entretanto, com concentração de escravos nas grandes propriedades. Apenas $10 \%$ dos inventários não possuíam escravos ${ }^{67}$. Tal população era predominantemente crioula (96\%); os africanos respondiam por apenas 3,9\% do total de escravos. O perfil das escravarias revela, portanto, alto grau de afastamento do mercado importador de cativos no país ${ }^{68}$.

A pesquisadora também constatou no período relativo equilíbrio entre os sexos e elevado índice de vínculos parentais entre os escravos: $65,2 \%$ deles possuíam laços de família primários ${ }^{69}$. Nas maiores escravarias ${ }^{70}$, a historiadora chegou a localizar famílias nucleares numa proporção de $77,5 \%$, sendo $72 \%$ das famílias unidas há mais de dez anos ${ }^{71}$. A frequência desses laços e sua recorrência temporal demonstram a sobrevivência das famílias e o crescimento na formação de parentesco, indícios que sugerem a estabilidade e antiguidade principalmente das maiores escravarias em Vitória.

Utilizando-se de mesmo aporte documental para análise da região sul da província entre 1850 e 1871, Geisa Ribeiro verificou que $95,8 \%$ dos inventariados eram proprietários de escravos, percentual superior ao verificado por Patrícia Merlo para o centro da provín$\mathrm{Cia}^{72}$.

Na região sul, a concentração de cativos era ainda mais elevada que no centro ${ }^{73}$. Dedicada à agricultura de exportação, Geisa Ri-

67 Nesse período, a historiadora calculou $41 \%$ de escravos vivendo em pequenos e médios plantéis e 59\% pertencentes a propriedades com mais de 20 escravos. MERLO, Patrícia Maria da Silva. O nó e o ninho: estudo sobre a família escrava em Vitória, Espírito Santo, 1800-1871. Tese (Doutorado em História), UFRJ, Rio de Janeiro, 2008. p. 156.

68 Nesse sentido, ver: MACHADO, Cacilda; FLORENTINO, Manolo. Famílias e mercado: tipologias parentais de acordo ao grau de afastamento do mercado de cativos: século XIX. Afro-Ásia, nº 24, 2000. p. 51-70.

69 MERLO, Patrícia Maria da Silva, Op. Cit., 2008. p. 160.

70 Acima de vinte escravos.

71 MERLO, Patrícia Maria da Silva, Op. Cit., 2008. p. 161.

72 RIBEIRO, Geisa Lourenço. Enlaces e desenlaces: família escrava e reprodução endógena no Espírito Santo (1790-1871). Dissertação (Mestrado em História). Ufes, Vitória, 2012.

73 Num total de 46 inventários, Geisa Ribeiro constatou que cinco deles reuniam um terço da população cativa inventariada na região sul. Se considerados apenas os inventários com mais 
beiro informa que os africanos representavam $31,7 \%$ da população escrava. A pesquisadora também encontrou nos inventários maior disparidade sexual entre esses cativos do que a verificada na região central da província: entre 1850 e 1871, 57,4\% dos escravos eram homens $\mathrm{s}^{74}$. O maior percentual de homens refletia o poder de arregimentação da mão de obra cativa por parte daqueles senhores que dispunham de maiores recursos para participar do tráfico. Dos africanos, $71,8 \%$ (181) eram homens e 28,2\% (71) eram mulheres.

Contudo, entre os escravos crioulos, $48,1 \%$ (260) eram homens e $51,9 \%$ (281) eram mulheres ${ }^{75}$. A força da população escrava crioula se direcionava, portanto, no sentido de equilibrar os sexos. Para Geisa Ribeiro, a superioridade feminina obriga a pensar na importância dos nascimentos para a reprodução do escravismo naquela área, isto é, na valorização da capacidade genésica da população escravizada, comprovada pelo elevado número de nascimentos de escravos em Itapemirim.

A pesquisadora conclui - com a constatação da grande proporção de crianças na composição das escravarias do sul do Espírito Santo (39,5\% de todos os escravos), proporcionalmente maior até do que o verificado no centro da província $(38,2 \%)$ - que a reprodução natural não se apresentou como estratégia viável para manutenção do escravismo apenas em regiões de economia de subsistência ${ }^{76}$. À semelhança do que ocorria em áreas afastadas do tráfico atlântico e, após 1850, do interprovincial, as famílias se revelaram

de 20 cativos, os números tornam-se ainda mais sugestivos, uma vez que 16 inventariados, ou o equivalente a um terço do total, detinham, sob seu domínio, $76 \%$ da escravaria. Segundo a historiadora, este percentual, além de ser revelador das grandes fazendas no sul, evidencia sua especificidade na província. RIBEIRO, Geisa Lourenço, Op. Cit., 2012. p. 116.

74 Ibidem, p. 112.

75 Ibidem, p. 122-123.

76 Em análise quantitativa de inventários post-mortem Geisa Ribeiro identificou, entre 1850-1871, num total de 1.332 escravos inventariados na região central, que 38,21\% tinham idade entre 0-14 anos; $47,98 \%$, entre $15-45$ anos e 13,81\%, 46 anos ou mais. Tratando-se da região sul, a pesquisadora encontrou, num total de 843 escravos arrolados, 39,5\% com idade de 0-14 anos, 49,22\%, entre $14-45$ e 11,28\% com 46 anos ou mais. RIBEIRO, Geisa Lourenço, Op. Cit., 2012. p. $131-132$. 
de grande importância para a manutenção e ampliação da mão de obra escrava nos domínios da grande lavoura espiritossantense.

Tais pesquisas contrariam a hipótese de Nara Saletto de que os senhores recorreram à compra de crianças na região de Vitória. $\mathrm{A}$ tentativa de explicar o fato de $30 \%$ (2009) da população cativa de Vitória ser composta por crianças (com idade entre 1-10 anos) ${ }^{77}$ se baseia apenas no recenseamento da época (1872) e em exemplos de outras regiões do Sudeste, como o estudo de Warren Dean, que identifica a maior parte da venda de escravos em Rio Claro (SP) composta de meninos entre 10 e 15 anos; e de Emília Viotti, que identifica o menor preço das crianças no comércio de escravos. Ao estabelecer sua hipótese, Nara Saletto não confrontou outras fontes que foram utilizadas por Patrícia Merlo e Geisa Ribeiro, como inventários post-mortem e registros eclesiásticos, além dos dados estatísticos, o que possibilitou maior densidade aos estudos sobre a escravidão e a família escrava no Espírito Santo.

Diante do exposto, é possível afirmar que o Espírito Santo, diferentemente de parte da tese da substituição da mão de obra escrava vista anteriormente, não sofreu impacto na manutenção da escravidão com a lei de 1850. É notório, inclusive, o crescimento vertiginoso da população escrava no período. Ainda que houvesse outras estratégias para abastecimento de mão de obra cativa na região, a solução para a manutenção da escravidão até 1871 estava na família escrava. Dito de outra forma, a reprodução endógena foi a responsável, em grande medida, pelo alto índice de crescimento dessa população.

Nesse contexto não surpreende o fato de os fazendeiros, principalmente da região sul, não demostrarem preocupação com a substituição da mão de obra escrava em suas lavouras. Os núcleos coloniais de imigrantes estrangeiros incentivados pelo governo eram vistos por eles com relativa indiferença. Essa atitude passiva da grande lavoura cafeeira pode ser explicada pelo fato de estar suficientemente abastecida de mão de obra escrava, concentrada primordialmente no sul da província, e de seus proprietários estarem

77 SALETTO, Nara, Op. Cit., 1996. p. 75. 
seguros da permanência de um sistema tão lucrativo e enraizado na sociedade como o escravista.

A partir de 1871, contudo, através de um processo orientado politicamente, houve a aplicação de leis que afrouxaram pouco a pouco os laços entre senhores e escravos, e levaram, ao final, à abolição completa e irrestrita. Veremos a seguir o impacto de tais leis na demografia escrava do Espírito Santo.

À progressiva queda (1871-1888)

O ano de 1871 foi fundamental na desmontagem da escravidão no Brasil. Em 28 de setembro daquele ano, foi transformado em lei $\left(n^{\circ} 2.040\right)$ um projeto apresentado à Câmara dos Deputados meses antes (em maio) que propunha a emancipação das crianças recém-nascidas de mulheres escravas. Segundo Robert Conrad, essa solução já havia sido legislada no Chile em 1811, na Colômbia em 1821, em Portugal em 1856, nas colônias do Caribe em 1870 e recomendada por Abraham Lincoln para Delaware em $1861^{78}$.

A lei de 1871 constituía-se num processo orientado politicamente no sentido de estabelecer gradualmente a passagem para um sistema de trabalho livre sem causar mudança imediata na agricultura ou nos interesses econômicos. Sabe-se que houve forte resistência dos grandes fazendeiros produtores de café do Centro-Sul do Império. Apesar de forte pressão, a lei, aprovada sob a administração conservadora de Rio Branco, acabou por eliminar a última fonte de renovação de mão de obra escrava ao declarar livres os filhos de mulheres escravas que nascessem a partir do dia 28 de setembro.

Antes de tratarmos do art. $1^{\circ}$, o mais conhecido e que acabou popularizando a legislação como Lei do Ventre Livre, vejamos o impacto de outros dispositivos contidos nela para a emancipação gra-

78 CONRAD, Roberto, Op. Cit., 1975. p. 112. 
dual dos escravos com foco na população cativa do Espírito Santo. Comecemos pelo fundo de emancipação.

\section{Liberdades controladas: fundo de emancipação}

Este estudo coaduna com um olhar mais recente de historiadores que utilizam como objeto de pesquisa o fundo de emancipação ${ }^{79}$. Tais estudos iniciaram no período de celebrações do centenário da abolição e permitiram uma renovação do pensamento sobre o tema. Apesar de não contestarem a visão da historiografia tradicional ${ }^{80}$ - centrada no fato de o fundo de emancipação ter encontrado na má vontade de muito senhores e agentes públicos um grande obstáculo à sua plena realização -, acredita-se que esse mecanismo, como bem destaca Fabiano Dauwe, "atendeu a objetivos muito definidos, que não eram o de libertar escravos em grande escala, mas o de fazê-lo dentro de critérios definidos, que previam justamente uma pequena quantidade de libertações" ${ }^{\prime 81}$.

79 Cf.: DAUWE, Fabiano. A libertação gradual e a saída viável. Os múltiplos sentidos da liberdade pelo fundo de emancipação de escravos. Tese (Dissertação de Mestrado). UFF, Niterói, 2004.

80 O fundo de emancipação foi tradicionalmente considerado pela historiografia (Emilia Viotti e Robert Conrad) uma forma de libertação "ineficiente" "ou ineficaz". Na década de 1870, Robert Conrad demonstrava que "o fundo de emancipação não conseguiu alcançar resultados notáveis" devido à falta de incentivos do governo para que a tarefa fosse realizada nas províncias e porque o fundo nunca teria chegado a ser suficientemente importante para libertar um grande número de escravos, em especial com os preços elevados que eram decididos localmente através de arbitragem. O pesquisador também afirmou que o fundo de emancipação não tinha a intenção de ser muito mais do que um gesto humanitário, um instrumento de libertação menor ou uma prova de boa vontade. Na pior das hipóteses, foi um meio para os proprietários se desembaraçarem dos seus escravos menos úteis a preços muito satisfatórios (CONRAD, Roberto, Op. Cit., 1975. p. 141). Tal visão, de incapacidade de se constituir em um instrumento de manumissão em grande escala, acabou contribuindo para a sua desqualificação, durante muito tempo, como objeto de interesse historiográfico.

81 DAUWE, Fabiano. Liberdade inconveniente: os múltiplos sentidos da liberdade pelo fundo de emancipação de escravos. In: X ENCONTRO ESTADUAL DE HISTÓRIA, 2010, UFSM. Anais do $X$ Encontro Estadual de História: O Brasil no Sul: cruzando fronteiras entre o regional e o nacional. São Paulo, UFSM, 2010. p. 1. Disponível em: http://www.eeh2010.anpuh-rs.org.br/ site/anaiscomplementares. Acesso em: 05/01/2016. 
As pesquisas têm se fundamentado na ideia de que cada dispositivo estabelecido na lei de 1871 deve ser compreendido como tendo uma finalidade e uma intencionalidade bem determinadas para não se correr o risco, em análises de comparações numéricas, de desconsiderar a relevância dos efeitos do fundo de emancipação. É com esse olhar que serão analisadas as informações sobre o fundo encontradas nos relatórios de presidente de província do Espírito Santo.

Antes disso, vale destacar o fato de no Espírito Santo ter sido criada lei provincial para a manumissão de escravos anterior à Lei Rio Branco. Tal medida foi fruto das ideias de uma abolição gradual da escravatura que ganhava forma em vários pontos do Império, devido ao movimento emancipacionista ${ }^{82}$. A Lei Provincial $n^{\circ} 25$ de 4 de dezembro de 1869 autorizava "a despesa anual de 6:000\$000 com alforrias de escravas de 5 a 10 anos de idade" ${ }^{\prime \prime 3}$. No ano seguinte, em 25 de setembro de 1870, segundo Daemon, em cumprimento dessa lei, foram alforriadas na capital 15 mulheres escravas, pelo fundo de emancipação ${ }^{84}$.

Outra Lei Provincial, de n 30, foi criada em 11 de dezembro de 1871, pouco mais de dois meses após a Lei Rio Branco. Aquela lei "consignou a quantia de 6:000\$000 anualmente para a manumissão de escravos do sexo feminino, da idade de 12 a 35 anos, por preço não excedente de um conto de reis cada um" ${ }^{\prime 85}$. Segundo relatório do presidente de província Antônio de Paula Fonseca, houve trinta e cinco requerimentos apresentados pelos senhores das escravas

82 O movimento emancipacionista foi fortalecido em 1869 com o aparecimento de clubes abolicionistas e de um incipiente jornalismo antiescravista. Segundo Vilma Almada, nesse ano fundou-se a Sociedade Abolicionista do Espírito Santo, cujo objetivo era o de "alforriar o maior número possível de escravos de qualquer idade e fazer deles cidadãos úteis, velando sobre a sua instrução religiosa, moral e literária, conforme as circunstâncias pecuniárias de sua identidade social". ALMADA, Vilma Paraíso Ferreira de, Op. Cit., 1984. p. 190.

83 Relatorio lido no paço d'Assembléa Legislativa da provincia do Espirito-Santo pelo prezidente, o exm. senr. doutor Francisco Ferreira Correa na sessão ordinaria no anno de 1871. Victoria: Typ. do Correio da Victoria, 1872. p. 133.

84 DAEMON, Basílio Carvalho, Op. Cit., 2010. p. 446.

85 Relatorio apresentado a Assembléa L. Provincial da provincia do Espirito Santo, 1872. p. 17, 18. 
que se propuseram a obter o benefício da manumissão outorgado pela lei, subindo a soma dos valores das pretendentes a mais de 28:000\$000. A comissão nomeada ${ }^{86}$ escolheu entre as propostas nove que reuniam em seu favor os motivos de preferência de que trata a lei: quatro residentes na capital, duas na Serra, uma em Carapina, Queimado e Guarapari Para a execução da referida lei, as cartas de liberdade foram produzidas e entregues pela presidência às libertadas no dia 7 de setembro, em sessão pública, no palácio, como constava no regulamento.

Ainda no mesmo ano (1871), o presidente de província Francisco FerreiraCorrea ${ }^{87}$ deuexecuçãoàLein.25de 1869, autorizandoadespesa anual de 6:000\$000 com alforrias de escravas de 5 a 10 anos de idade.

Até o dia 7 de setembro foram apresentadas 15 petições de pessoas que pretendiam o favor da lei para suas escravas. Foi nomeada uma comissão ${ }^{88}$ para dar parecer sobre essas petições que, a 29 de setembro, dava conta do resultado dos seus trabalhos, opinando pela preferência de onze escravas: três em Vitória, quatro em Guarapari, uma em Cariacica, Mangaray, Serra e Espírito Santo. Em 25 de setembro, foram enviados todos os papéis concernentes às libertandas preferidas à Tesouraria provincial a fim de se expedirem as cartas de liberdade.

Mais uma vez, as falas dos relatórios sugerem alterações a respeito da preferência pelo menor preço relativo de cada alforria e a respeito da idade de cinco a dez anos prescrita na lei.

As discussões na província a respeito das exigências da lei giravam, portanto, no sentido de diminuir a faixa de idade das futuras

86 "Para dar cumprimento a ultima parte do art. $2^{\circ}$ da citada lei, foi nomeada uma comissão composta do dr. chefe de Polícia interino, Fernando Affonso de Mello, do juiz de Fazenda desta comarca dr. Luiz Duarte Pereira, e do inspetor da Tesouraria de Fazenda Geral Thomé Arvellos Espinula".

87 Relatório do exmo. senhor doutor Francisco Ferreira Correa, 1872. p. 132-136.

88 A comissão era composta pelo chefe de Polícia, bacharel Antônio Joaquim Rodrigues, pelo presidente juiz de Direito interino, bacharel Fernando Affonso de Mello, pelo juiz municipal suplente, capitão João Chrysostomo de Carvalho, pelo promotor público da capital, bacharel Cassiano Cândido Tavares Bastos, e pelo procurador fiscal da Fazenda provincial, tenente Francisco Urbano de Vasconcellos. 
libertandas, cogitando uma idade mais suscetível à instrução ou, ao contrário, aumentá-la, para evitar a permanência das relações de dependência de seu ex-senhor. É evidente também, nos discursos dos presidentes de província, a satisfação em implantar um processo gradual de libertação encampado pelo governo imperial e colocado em prática, ainda que se tratando da alforria de um número pequeno de escravos.

Sabemos, contudo, que a totalidade dos votos dos deputados que representaram o Espírito Santo na Câmara foi contrária à sanção da lei de 28 de setembro de $1871^{89}$. Tal reação, que revela o apego à mão de obra escrava na província, não surpreende tratando-se de grandes fazendeiros das zonas cafeeiras, interessados na conservação do regime escravista.

Diante do exposto cabe ressaltar um dado por ora curioso: assim como nas libertações mencionadas anteriormente, não houve nenhuma libertanda residente na região sul cafeeira. Muito provavelmente sequer constara petição de senhores de escravas do reduto cafeeiro dessa província.

A seguir será analisado como se procederam às libertações do fundo de emancipação criado pela lei de 1871 no Espírito Santo, com destaque para as duas regiões em foco neste trabalho.

No art. $3^{\circ}$ da Lei Rio Branco de $1871^{90}$ ficou estabelecido que seriam anualmente libertados em cada província do Império tantos escravos quantos correspondessem à quota anualmente disponível do fundo ${ }^{91}$ destinado à emancipação. Os recursos arrecadados para o fundo eram repartidos entre cada província proporcionalmente

89 Conferir tabela 21: Votos na Lei Rio Branco em CONRAD, Robert, Op. Cit., 1975. p. 362.

90 Disponível em: http://www.planalto.gov.br/ccivil_03/leis/LIM/LIM2040.htm. Acesso em: 26/12/2015.

91 Segundo a lei, o fundo de emancipação compõe-se: da taxa de escravos; dos impostos gerais sobre transmissão de propriedade dos escravos; do produto de seis loterias anuais isentas de impostos e da décima parte das que forem concedidas d'ora em diante para correrem na capital do Império; das multas impostas em virtude desta lei; das quotas que sejam marcadas no Orçamento geral e nos provinciais e municipais; e, por fim, de subscrições, doações e legados com esse destino. 
ao número de escravos que contivessem. O mesmo critério servia para a distribuição em cada município.

Para que essa tarefa fosse possível, o artigo $8^{\circ}$ da Lei Rio Branco de 1871 ordenou proceder à matrícula especial de todos os escravos realizada por juntas especialmente constituídas para isso em cada município ${ }^{92}$.

Apesar de ter sido estabelecido no papel um sistema de registro e classificação, segundo Robert Conrad, o governo "pouco fez para assegurar que o trabalho fosse realmente realizado nas centenas de municípios do Império" ${ }^{13}$. Na província do Espírito Santo, constam em três relatórios de presidente de província - em $1877^{94}$, $1878^{95}$ e $1882^{96}$ - com informações sobre a matrícula especial dos escravos referente à lei de 1871 . O primeiro revela a dificuldade na organização do quadro estatístico solicitado pelo Ministério e, nos outros dois anos, há informações apenas de escravos residentes no município de Vitória e na vila do Espírito Santo.

92 Na matrícula dos escravos deveriam ser informados: nome, sexo, estado, aptidão para o trabaIho e filiação de cada um, se fosse conhecida. Mais de um ano após a promulgação da Lei Rio Branco, em 13 de novembro de 1872, o ministro da Agricultura decretou os regulamentos para o uso do fundo de emancipação. As famílias teriam preferência, no que se referia à libertação, sobre pessoas individuais, particularmente membros da família que fossem de propriedade de senhores diferentes, com a preferência dada aos pais de ingênuos, de crianças livres e de crianças escravas, respectivamente. Na seleção de pessoas individuais para manumissão, as mães e os pais com filhos livres e escravos entre as idades de doze e quinze anos seriam preferidos, começando com as mulheres mais jovens e os homens mais idosos. Isso libertaria as mulheres em idade de ter filhos, enquanto manteria os homens mais produtivos no trabalho. CONRAD, Roberto, Op. Cit., 1975. p. 134.

93 Ibidem, p. 135.

94 Relatório apresentado a Assembleia Legislativa da província do Espirito-Santo em a 2.a sessão ordinária da vigésima primeira legislatura provincial pelo presidente desta província, dr. Antonio Joaquim de Miranda Nogueira da Gama, aos 3 de março de 1877. Victoria: Typ. do Espirito-Santense, 1877

95 Relatório apresentado pelo exmo. senhor dr. Manoel da Silva Mafra a Assembleia Legislativa Provincial do Espirito-Santo no dia 22 de outubro de 1878. Victoria: Typ. da Actualidade, 1878.

96 Relatório com que o exmo. senhor dr. Herculano Marcos Inglez de Souza entregou no dia 9 de dezembro de 1882 ao exm. sr. dr. Martim Francisco Ribeiro de Andrada Junior a administração da província do Espirito Santo. 
A lentidão do registro e da classificação retardou, de fato, a aplicação do fundo de emancipação ${ }^{97}$. Entre 1875 e 1876, quase cinco anos depois da criação da Lei Rio Branco, foram libertados os primeiros escravos no Espírito Santo com a aplicação da primeira quota do fundo de emancipação.

Na fala com que o presidente de província Domingos Monteiro Peixoto instalou a Assembleia Provincial do Espirito Santo na sessão do dia 18 de setembro de 1875, foi declarado que o Ministério dos Negócios da Agricultura, Comércio e Obras Públicas, em aviso de 6 de abril do mesmo ano, comunicou haver sido marcada a quantia de 55:503\$458 para a libertação de escravos na província, por ato de 12 de agosto. Após sujeitada à aprovação do governo, foi feita a distribuição pelos municípios da maneira seguinte:

97 Em maio de 1874, mais de 3 mil contos já tinham sido acumulados no fundo, o suficiente para libertar quase 6.500 escravos a um preço médio de 500 mil-réis cada. CONRAD, Robert, Op. Cit., 1975. p. 137. 
Tabela 1

Fundo de emancipação da província do Espírito Santo -1875

\begin{tabular}{|c|c|c|c|c|}
\hline Municípios & $\begin{array}{l}\text { No de escravos } \\
\text { por município }\end{array}$ & $\begin{array}{l}N^{\circ} \text { de } \\
\text { escravos } \\
\text { emanci- } \\
\text { pados }\end{array}$ & $\begin{array}{l}\text { Quotas dis- } \\
\text { tribuídas }\end{array}$ & $\begin{array}{l}\text { Importância } \\
\text { despendida }\end{array}$ \\
\hline Victoria & 3.687 & \multirow{3}{*}{26} & & \multirow{3}{*}{$12: 359 \$ 140$} \\
\hline Espirito Santo & 511 & & & \\
\hline Viana & 1.257 & & $3: 800 \$ 000$ & \\
\hline Serra & 1.464 & 5 & 4:000\$000 & $3: 450 \$ 000$ \\
\hline Nova Almeida & 460 & 2 & $2: 400 \$ 000$ & $1: 600 \$ 000$ \\
\hline Santa Cruz & 466 & 6 & $2: 600 \$ 000$ & $2: 330 \$ 000$ \\
\hline Linhares & 172 & 2 & $1: 503 \$ 458$ & $628 \$ 000$ \\
\hline Barra de S. Mateus & 796 & 6 & $3: 200 \$ 000$ & $3: 150 \$ 000$ \\
\hline S. Mateus & 2.017 & 8 & $5: 000 \$ 000$ & $5: 000 \$ 000$ \\
\hline Guarapary & 417 & 4 & $2: 000 \$ 000$ & $2: 000 \$ 000$ \\
\hline Benevente & 1.057 & 6 & $3: 500 \$ 000$ & $3: 251 \$ 250$ \\
\hline Cachoeiro de Itapemirim & 7.482 & 9 & $12: 000 \$ 000$ & $11: 450 \$ 000$ \\
\hline Itapemirim & 2.873 & 4 & $5: 500 \$ 000$ & $5: 200 \$ 000$ \\
\hline Total & 22.659 & 78 & $55: 503 \$ 458$ & $50: 418 \$ 390$ \\
\hline
\end{tabular}

Fonte: Falla com que o exm. sr. dr. Domingos Monteiro Peixoto installou a Assembléa Provincial do Espirito-Santo na sessão do dia 18 de setembro de 1875. Victoria: Typ. do EspiritoSantense, 1875. Relatorio apresentado pelo exm.o sr. dr. Manoel José de Menezes Prado na installação da Assembléa Provincial do Espirito-Santo na sessão de 15 de outubro de 1876. Victoria: Typ. do Espirito-Santense, 1876.

Segundo Robert Conrad ${ }^{98}$, em maio de 1876, quase cinco anos depois da Lei Rio Branco, o governo do Império anunciou que 1.503 escravos haviam sido libertados pelo fundo, cerca de um em cada 1.000 registrados. No Espírito Santo foram 78 libertos (5\% do total) com a quota de 55:503\$458 destinada à província.

98 Ibidem, p. 138. 
De acordo com a tabela 1, havia em 1875 no Espírito Santo 22.659 escravos. A maior quota do fundo (12:000\$000) foi destinada a Cachoeiro de Itapemirim, município com maior quantidade de cativos da província (33\%). A segunda maior quota (10:000\$000) foi destinada aos municípios de Vitória e Espírito Santo. Juntos representavam 18,5\% dos escravos da província. Em terceiro lugar (5:500\$000) estava o município de Itapemirim, outro reduto da lavoura cafeeira. Saltam aos olhos, contudo, a diferença entre o número de escravos emancipados e a importância despendida para tanto nessas regiões. Considerando a libertação dos 26 escravos pertencentes a Vitória, Espírito Santo e Viana, encontramos uma média de $475 \$ 351$ gastos por escravo. Em Cachoeiro de Itapemirim, a média foi de 1:272\$222, mais que o dobro. Em Itapemirim a média chegou a 1:300\$000!

Se observarmos o total de escravos emancipados (78) com o que foi gasto, verificamos uma média de $646 \$ 389$ por escravo. 0 custo médio de libertações pelo fundo de emancipação encontrado, de acordo com os dados da tabela, se aproxima do que foi calculado por Robert Conrad ${ }^{99}$ para a província do Espírito Santo, 709\$000. Contudo, se consideramos as médias por município observamos grandes diferenças. Nem mesmo as médias de outras regiões do Centro-Sul, diga-se de passagem, as mais altas do Império, alcançaram tais valores ${ }^{100}$. Adiante serão analisadas outras informações a fim de se compreender as especificidades da região.

Em 19 de julho de 1880, em relatório do então presidente de província do Espírito Santo Eliseu de Sousa Martins ${ }^{101}$, foram convocadas juntas classificadoras dos escravos dos municípios a fim de ser aplicada a quota de $60: 184 \$ 530$ que, na segunda distribuição do fundo de emancipação, coube a província para ser distribuída por todos os municípios. Apesar de não informada a divisão das quotas

99 Tabela 23. Ibidem, p. 363.

100 Minas Gerais: 909\$000; Rio de Janeiro: 880\$000; Município neutro: 575\$000; São Paulo: 855\$000.

${ }^{101}$ Relatório com que o exmo. sr. dr. Eliseu de Sousa Martins no dia 19 de julho de 1880 passou a administração da província do Espírito Santo ao exm. sr. tenente coronel Alpheu A. Monjardim de A. e Almeida. $1^{\circ}$ vice-presidente. 
por região bem como o número de libertados nesse documento, o relatório de $1882^{102}$ expõe algo novo: o fato de que no ano anterior terem sido libertados em audiências de juízes de Órfãos 17 escravos pertencentes ao município de Cachoeiro que ainda não havia empregado as quotas da segunda distribuição feita pelo fundo de emancipação.

Em janeiro de 1882, foram convocadas as juntas classificadoras dos escravos dos municípios da província a fim de ser aplicada a quota de 34:892\$266 que na terceira distribuição do fundo de emancipação coube à província ${ }^{103}$. A referida quota seria distribuída por todos os municípios, segundo o número de escravos existentes, incluindo a importância ( $3: 356 \$ 103)$ das sobras que lhes competiam, resultantes das duas últimas distribuições.

Ao receber o aviso circular do Ministério dos Negócios da Agricultura, Comércio e Obras Públicas em dezembro de 1882, o presidente de província Martim Francisco Ribeiro de Andrada Junior ${ }^{104}$ convocou para o dia 15 de fevereiro de 1883 as juntas classificadoras dos escravos dos municípios da província para ser aplicada a quarta quota de 46:600\$000 do fundo de emancipação. A distribuição ${ }^{105}$ conferiu a Cachoeiro de Itapemirim, a capital ${ }^{106} \mathrm{e}$ a Itapemirim as maiores quantias. Cachoeiro de Itapemirim ficou com 20:000\$000, a capital com 7:000\$000 e Itapemirim com 4:532\$441. Com o produto da quarta distribuição da província libertaram-se 40 escravos, sendo 23 do sexo masculino e 17 do feminino. Despendeu-se com

102 Relatório com que o exmo. sr. dr. Marcellino de Assis Tostes, no dia 13 de fevereiro de 1882, passou a administração da província do Espirito-Santo ao exm. sr. tenente-coronel Alpheu Adelpho Monjardim de Andrade e Almeida, primeiro vice-presidente. Victoria:Typ. do Horizonte, 1882.

${ }^{103}$ Relatório do exm. sr. dr. Marcellino de Assis Tostes, 1882.

${ }^{104}$ Relatórioapresentadoá Assembleia Legislativa da província do Espirito-Santo pelo exmo.sr.dr. Martim Francisco Ribeiro de Andrada Junior em 3 de março de 1883. Victoria:Typ. do Horisonte, 1883.

105 Capital e Espirito Santo: 7:000\$000; Serra e Nova Almeida: 4:168\$633; Santa Cruz: 1:024\$009; Linhares: $500 \$ 000 ;$ Barra de S. Matheus: 1:035\$177; Cidade do mesmo nome: 3:500\$451; Vianna: 2:087\$776; Guarapary: 704\$056; Benevente: 2:016\$738; Itapemirim: 4:532\$441; Cachoeiro de Itapemirim: $20 \$ 000 \$ 000$. Total: $46: 569 \$ 281$. Na distribuição estão incluídas as sobras da última quota pertencentes a diferentes municípios na importância de $569 \$ 281$ rs.

106 Os valores também incluem, além da capital, a vila do Espírito Santo. 
as respectivas indenizações a quantia de $21: 735 \$ 930$, verificando-se um saldo de $24: 832 \$ 351$. Importa destacar que essa diferença se deve a não aplicação das quotas distribuídas aos municípios de Cachoeiro de Itapemirim e cidade da Serra, "cuja demora é notável e injustificável", na fala do presidente da província ${ }^{107}$.

Por fim, a quantia de 20:000\$000 que coube a província do Espírito Santo na sétima quota do fundo de emancipação Antônio Joaquim Rodrigues distribuiu proporcionalmente pelos municípios, deduzindo, na forma recomendada pelo Ministério da Agricultura, a quantia de 1:577\$623, equivalente ao déficit verificado na quinta quota distribuída no município de Benevente. Para Linhares mandou reunir a importância de $350 \$ 580$ que deixou de ser empregada na sexta distribuição, e adicionou aos demais municípios as sobras que lhes competiam na importância de 9:784\$179. O presidente convocou as juntas classificadoras para o dia 16 de junho. Elas se reuniram no referido dia, exceto em Benevente e Itapemirim, que designaram o dia 26 de julho para iniciar seus trabalhos. Chama atenção o fato de o presidente preocupar-se com o pequeno número de libertação pelo fundo de emancipação até aquele momento. Eram apenas seis escravos, sendo um do município de Guarapari, um da barra de São Matheus e quatro da cidade de mesmo nome.

A análise dos dados apresentados sobre o fundo de emancipação na província revela o elevado gasto do fundo com os escravos da região sul, uma média altíssima com o menor número de manumissões. Evidencia, ainda, as tardias distribuições do fundo de emancipação no município de Cachoeiro de Itapemirim, "notáveis e injustificáveis". Havia uma clara relutância dos fazendeiros em efetuar o processo gradual de libertação empreendido pelo governo. Ainda que se tratasse, como dito anteriormente, de um mecanismo de libertação que previa em seus critérios justamente uma pequena quantidade de alforrias, houve relutância dos fazendeiros da região sul em utilizar as quotas distribuídas.

\footnotetext{
${ }^{107}$ Relatório com que o exmo. sr. dr. Miguel Bernardo Vieira de Amorim, $2^{\circ}$ vice-presidente, passou a administração desta província ao exmo. sr. dr. Joaquim José Affonso Alves no dia 12 de janeiro de 1884. Victoria: Typ. do Horisonte, 1884.
} 
O fenômeno da grande variação da quantidade de escravos libertados pelo fundo de emancipação nos municípios do Espírito Santo foi encontrado em outras partes do Império, o que sugere haver uma relação inversamente proporcional entre a atuação do fundo em uma determinada localidade e o vigor econômica da região. Segundo Fabiano Dauwer ${ }^{108}$, em localidades como Campinas (SP) e Vassouras (RJ), grandes centros produtores de café, o fundo de emancipação teve uma atuação muito mais restrita do que em regiões de economia mais frágil, que libertaram quantidades de escravos comparativamente muito maiores e por valores muito inferiores aos estipulados nos grandes centros. Assim como nessas regiões produtoras de café, o sul do Espírito Santo, devido a motivações eminentemente econômicas, mostrou-se discrepante das outras regiões da província.

Mesmo assim, entre 1876, quando foi aplicado pela primeira vez, até 1887, ano da distribuição da última quota, o fundo libertou mais de 32 mil escravos em todo o país, despendendo para isso uma quantia superior a 27 mil contos de réis ${ }^{109}$. O Espírito Santo libertou 422 escravos $(2,1 \%)$ numa população escrava calculada, em 1885 , em 19.762. Menores médias apresentaram as províncias de Minas Gerais $(1,6 \%)$, Rio de Janeiro $(1,5 \%)$ e São Paulo $(0,6 \%)^{110}$.

O fundo de emancipação consistiu, portanto, em dispositivo coerente com o espírito da Lei do Ventre Livre, que era o de encaminhar a extinção da escravidão no Brasil da forma mais lenta e gradual possível, alterando pouco as estruturas políticas e sociais do país. Dessa forma, compreende-se que o objetivo não era o de obter libertações em massa e, sim, garantir algumas liberdades de forma controlada. De acordo com Dauwe ${ }^{111}$, o fundo era, inclusive, uma forma de se garantir a manutenção da autoridade senhorial sobre o antigo escravo, ao mesmo tempo em que se buscava vinculá-lo ao poder público. Nesse processo, objetivava-se, portanto, obter a

\footnotetext{
${ }^{108}$ DAUWE, Fabiano, Op. Cit., 2010. p. 8.

109 Ibidem, p. 2.

${ }^{110}$ ALMADA, Vilma Paraíso Ferreira de, Op. Cit., 1984. p. 192.

111 DAUWE, Fabiano, Op. Cit., 2004. p. 97.
} 
gratidão do liberto aos seus dois libertadores: o Estado e o antigo senhor.

Além da liberdade conquistada pelo fundo de emancipação, havia também outros meios de adquiri-la. Foram contabilizados em livros cartoriais de escrituras de compra e venda de Vitória (ES) 114 registros de cartas de liberdade entre 1871 e 1888. Nos documentos constam liberdades conquistadas por meio de pecúlio, em conformidade com a lei de 1871. Graças a ela foi concedido ao escravo o direito legal de adquirir pecúlio por meio de doações, legados e heranças ou proveniente das economias de seu trabalho. Assegurado o pecúlio, o escravo poderia comprar sua própria liberdade quando tivesse a quantia em dinheiro igual ao seu valor.

\section{Liberdades controladas: das crianças aos sexagenários}

Por último, o artigo $1^{\circ}$ da lei de 1871 considerava livres os filhos das mulheres escravas que nasceram no Império desde a data da lei, obrigando seus senhores a cuidar deles até a idade de oito anos, quando, então, os donos das mães poderiam escolher entre receberem do Estado uma indenização de 600 mil reis em títulos de trinta anos a seis por cento ou usarem o trabalho dos menores (ingênuos) até eles alcançarem a idade de vinte e um anos.

Para aferir o impacto da lei na população escrava da província foram utilizados os registros de batismos da Paróquia de Nossa Senhora da Vitória constantes em livro cujas folhas foram assinadas, numeradas e rubricadas pelo chefe de Polícia do Espírito Santo, Antônio Joaquim Rodrigues, em 6 de novembro de 1871. A confecção de um livro especial tratava-se de uma exigência do artigo $8^{\circ}$ da lei de 28 de setembro de 1871 para o registro de nascimentos dos filhos de escravas nascidos desde então, cuja omissão do pároco levaria ao pagamento de uma multa de $100 \$ 000$ reis $^{112}$.

\footnotetext{
112 Segundo Adriana Campos, sobre o documento de batismo como prova de liberdade, foram apresentados o título $25, £ 5^{\circ}$, do livro $3^{\circ}$ das Ordenações Filipinas e o alvará 29 de 23 de fevereiro de 1848 (Colleção, 1849. p. 30). Tais dispositivos confirmavam as certidões de batismo como documentos com capacidade comprobatória de liberdade (Acórdão, 16/02/1855). Cf. CAMPOS,
} 
Importa destacar que apesar de o livro ter sido aberto ainda no mesmo ano da lei, os primeiros assentos datam de 1875. Como o documento encontra-se bastante deteriorado, não se sabe se possui preservadas todas as suas folhas. Também chama atenção o fato de os registros estarem fora da ordem cronológica. Portanto, fica a incerteza se folhas se perderam e/ou se os filhos de escravas nascidos imediatamente após a lei ou nos primeiros anos seguintes simplesmente não foram registrados por omissão dos senhores.

Vejamos o gráfico com a frequência de batismos de filhos de escravas antes e depois da Lei Rio Branco:

\section{Gráfico 3}

Frequência de batismos de filhos de escravas

antes e depois da Lei Rio Branco

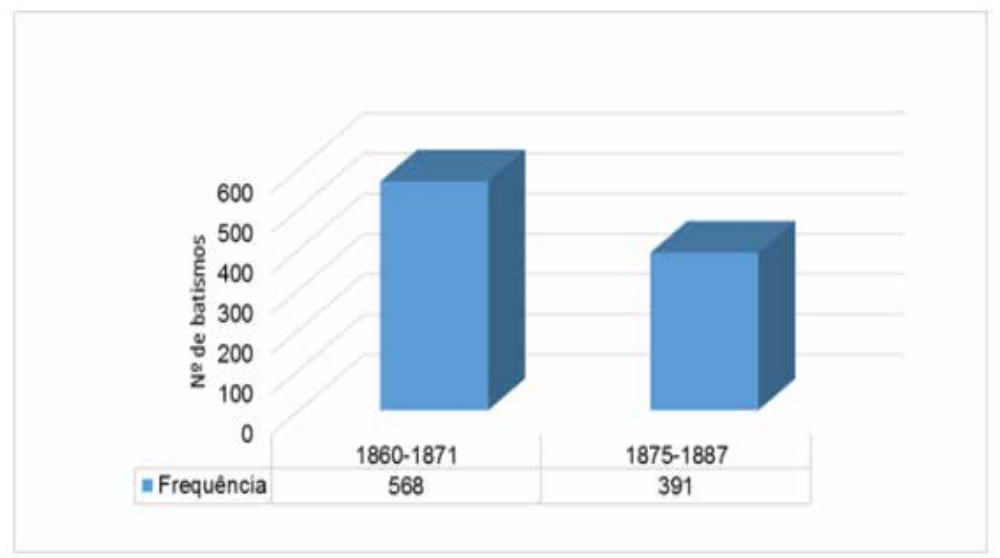

Fontes: Cúria Metropolitana de Vitória. Livro de batismo de escravos da Catedral. L.04B, 1859-1872. Cúria Metropolitana de Vitória. Livro de batismo de filhos de escravos que nasceram depois da lei de 1871. L.05B, 1871-1887.

Adriana Pereira. Prescrição da escravidão e a "liberdade oprimida" no Brasil dos Oitocentos. Revista de História (São Paulo), vol. 34, n. 2, p. 206-220, jul./dez. 2015. p. 214. 
Os dados do gráfico acima foram retirados do livro de batismos de escravos da Paróquia de Nossa Senhora da Vitória e do livro especial criado depois da lei de 1871 na mesma localidade. Entre 1860 e 1871, foram batizados 568 escravos. Apesar de terem sido realizados batismos até o dia 28 de dezembro de 1871, 46 cativos receberam o sacramento nesse ano; as datas dos nascimentos são anteriores ao dia 28 de setembro. Flora, filha natural de Germana e escrava do doutor Jose de Melo e Carvalho foi batizada no dia primeiro de outubro e seu nascimento consta de 18 de agosto ${ }^{113}$. Ela foi a última escrava registrada com data de nascimento anterior à publicação da lei na região. Se a data do nascimento, às vésperas da lei, foi fruto do destino ou estabelecida por estratégia de seu senhor nunca saberemos.

Raros são os documentos que fornecem luz sobre essa questão. Michel Dal Col Costa ${ }^{114}$ encontrou em pesquisa em inquéritos policiais em Vitória o que chamou de um "excepcional processo". Segundo o historiador, meses depois da declaração da Lei do Ventre Livre, membros da comunidade de São José do Queimado, próximo à cidade de Vitória, com a ajuda do vigário da paróquia, acusaram um importante senhor de escravos de ter buscado fraudar o registro de nascimento no batismo de duas crianças nascidas de duas mulheres pertencentes a sua escravaria. Acusavam Manoel Francisco Feu de Araújo de manter sob cativeiro duas crianças que haviam nascido após a Lei do Ventre Livre, e não meses e dias antes, como alegava esse senhor ${ }^{115}$. Apesar de não indicar um veredicto, o processo, segundo Michel Dal Col, deixa claro uma espécie de luta de um grupo social comunitário que buscou fazer pressão com intuito de tolher ou diminuir o domínio de um importante senhor de escravos da

${ }^{113}$ Cúria Metropolitana de Vitória. Livro de batismo de escravos da Catedral. L.04B, 1859-1872. Folha $s / n$.

${ }^{114}$ COSTA, Michel Dal Col. Guerra internacional e batalhas do cotidiano: a comarca de Vitória/ ES no programa imperial de extinção gradual da escravidão. In: SEMINÁRIO INTERNACIONAL BRASIL NO SÉCULO XIX. Niterói, 2015. Anais do Seminário Internacional Brasil no Século XIX. Niterói: Sociedade de Estudos dos Oitocentos SEO, 2015. p. 1-19. Disponível em: http://www. seo.uff.br/images/Anais/Arthur/Michel\%20Dal\%20Col.pdf.

115 COSTA, Michel Dal Col, Op. Cit., 2015. p. 6. 
região, se apropriando da lei proclamada em âmbito nacional para usar na sua prática política local.

De volta à análise do gráfico, após três anos de lacuna, constam, em 1875, apenas 20 nascimentos de filhos de escravas, ou seja, menos da metade em relação aos anos anteriores. Em 1876, o número se normaliza e alcança 47 batismos. Em 1877, 38 inocentes foram batizados e, em 1878, 41.

Dentre os 391 ingênuos nascidos sob a égide da Lei do Ventre Livre, seis $(1,5 \%)$ foram plenamente libertos das condições em que viviam sujeitos em virtude da lei antes de completar um ano de idade, ou seja, os senhores desistiram dos serviços pelos quais tinham direito. Eram eles: Manoel, filho de Margarida, escrava de Manoel Francisco Gomes; Artur, cuja mãe pertencia a dona Francisca Martins Ferreira Meireles ${ }^{116}$; Gratutina, filha de Isabel, escrava de dona Delfina Maria da Conceição Resende; Crenolina, filha de Jesuina, escrava de João Jacob Tosch; Manoel, filho de Germana, escrava de Manoel Gomes das Neves Pereira e Augusta, filha de Rosinda, escrava do capitão Martins de Azambuja Meireles ${ }^{117}$.

A partir dessas informações podemos assegurar que os senhores preferiam utilizar os serviços dos "filhos da lei Rio Branco" até atingirem os 21 anos de idade do que receber a indenização do Estado e conceder a liberdade a eles. Segundo Joseli Mendonça ${ }^{118}$, ao mesmo tempo em que a lei desapropriou os senhores dos frutos do ventre de suas escravas, outorgou-lhes a exclusividade da escoIha sobre o destino das crianças que tornara livres e estabeleceu a possibilidade da manutenção do atrelamento pessoal, tornando essas crianças obrigadas à prestação de serviços aos senhores de suas mães.

Corroborando as informações sobre os batismos de ingênuos filhos de escravas em Vitória, observa-se nas estatísticas do governo

\footnotetext{
116 Não foi possível ler o nome da mãe.

117 Cúria Metropolitana de Vitória. Livro de batismo de filhos de escravos que nasceram depois da lei de 1871. L.05B, 1871-1887. Folhas: 41, 70, 71, 78, 80, (ilegível).

118 MENDONÇA, Joseli Maria Nunes. A lei de 1885 e os caminhos da liberdade. Dissertação (Mestrado). Universidade Estadual de Campinas, Campinas, 1995. p. 66.
} 
uma diminuição mínima do número de escravos na província entre 1871 e 1874, quando, a partir de então, inicia-se um declínio mais acentuado dessa população. Vejamos o gráfico 4:

\section{Gráfico 4}

\section{Declínio da população escrava do Espírito Santo}

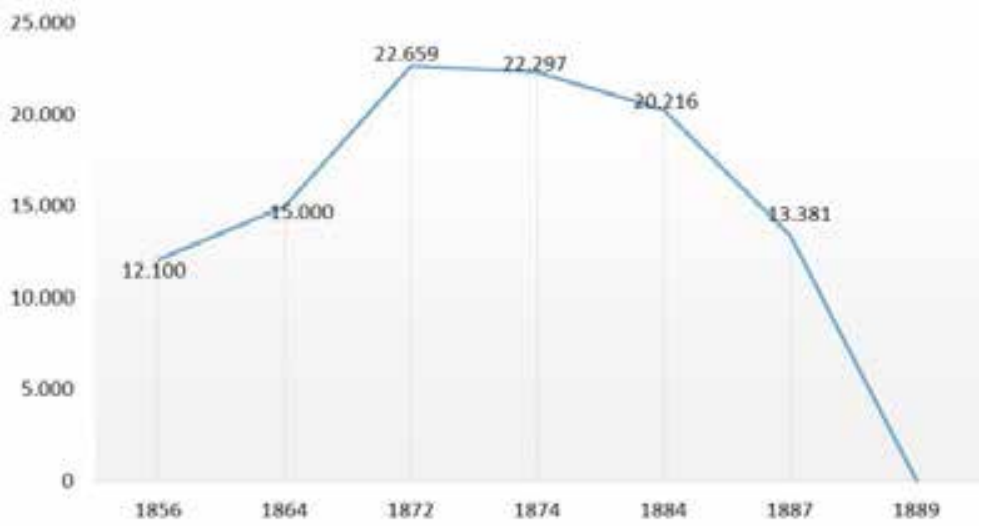

Fontes: 1856: Relatório com que o exm. snr. presidente da província do Espírito Santo, o doutor José Mauricio Fernandes Pereira de Barros, passou a administração da província ao exmo. sr. comendador, José Francisco de Andrade e Almeida Monjardim, segundo vice-presidente, no dia 13 de fevereiro de 1857; 1872: Recenseamento Geral do Império, 1872. Diretoria Geral de Estatística. Rio de Janeiro: Typ. Leuzinger/Tip. Comercial, 1876, 12 volumes. Disponível em: http://biblioteca.ibge.gov.br/; 1864, 1874, 1884 e 1887: Perdigão Malheiro, A escravidão, II, 198; Relatório do Ministério da Agricultura, 10 de maio de 1883, p. 10; Ibidem, 30 de abril de 1885, p. 372; Ibidem, 14 de maio de 188, p. 24. Apud CONRAD, Roberto, Op. Cit., 1975. p. 346.

Na primeira parte do artigo foram destacados e analisados momentos de crescimento da população cativa na província, que alcançou números nunca antes vistos no local (22.659). A partir de então, como notório no gráfico, este índice sofreu de tímida a acentuada queda. Entre 1872 e 1874, o declínio foi tênue (eram menos 362 cativos). Já entre 1874 e 1884, observou-se uma queda considerável de 2.081 pessoas. Em 1887, havia 6.835 escravos a menos na província, que passou a contar com uma população 
de 13.381 mancípios. Ainda assim, observamos no Espírito Santo, às vésperas da abolição, pouco mais da metade do contingente escravo calculado em 1872, o que evidencia a dificuldade dos proprietários de escravos em romperem com tal instituição.

A Lei do Ventre Livre, apesar de não causar um impacto imediato na diminuição da população cativa na província do Espírito Santo, contribuiu significativamente para o colapso da escravatura ao comprometer a última fonte de abastecimento de mão de obra cativa: o ventre das escravas. Mesmo dependente dessa mão de obra até as vésperas da abolição, não havia mais condições de impedir o declínio de tal instituição no Espírito Santo.

Os dados de relatórios de presidentes de província a respeito da matrícula especial dos escravos e dos filhos livres de mulheres escravas em 1878 e 1882 podem nos ajudar a compreender melhor o declínio de escravos na província.

Em $1878^{119}$, foram matriculados, de acordo com a lei de 28 de setembro de 1871, 4.089 escravos residentes nos municípios da cidade de Vitória e da vila do Espirito Santo. Desses, faleceram 318 e foram libertos 336 , achando-se, portanto, aquele número reduzido a 3.435. No mesmo período foram matriculados 979 menores livres filhos de escravos, dos quais 217 faleceram, restando 732 .

Em $1882^{120}$, os dados foram atualizados. Havia 4.089 escravos matriculados e residentes nos municípios da cidade de Vitória e da vila do Espirito Santo e 358 averbados, totalizando 4.447 cativos. Faleceram 413 cativos, 280 mudaram-se para fora do município e 514 foram libertados, ficando reduzido a 3.240 o número de escravos matriculados e averbados. Dos filhos livres de mulher escrava foram entregues às mães libertas 46, ao Estado por opção de serviço 80. Restavam 1.018, sendo 509 homens e 509 mulheres.

\footnotetext{
119 Relatório apresentado pelo exmo. sr. dr. Manoel da Silva Mafra a Assembleia Legislativa da província do Espirito-Santo no dia 22 de outubro de 1878. Victoria: Typ. da Actualidade, 1878.

${ }^{120}$ Relatório com que o exmo. sr. dr. Herculano Marcos Inglez de Souza entregou no dia 9 de dezembro de 1882 ao exmo. sr. dr. Martim Francisco Ribeiro de Andrada Junior a administração da província do Espirito Santo.
} 
Em relatório de $1886^{121}$, consta que a população escrava do município da capital e do da vila do Espirito Santo atingiu, até o encerramento da matrícula, o número de 4.090. Até a data, haviam falecido 501 cativos, 753 mudaram de município e 1.015 foram libertados, ficando o número de escravos matriculados e averbados reduzido a 2.661. Neles também estão compreendidos não apenas os libertos, mas também os que atingiram a idade de 60 anos. Com referência aos filhos livres de mulher escrava, observou-se que o número deles subiu nos dois municípios a 1.762 e, com o falecimento de 507 deles, ficou reduzido a 1.255 o número de homens e mulheres.

Com base nesses números podemos visualizar com detalhes a diminuição da população escrava na região central da província. Não temos informações sobre a libertação de cativos da região sul para efeito de comparação. Contudo, os dados informados por Nara Saletto ${ }^{122}$ são elucidativos. Segundo a pesquisadora, a região de Cachoeiro de Itapemirim teve sua população de escravos crescente até 1879 (em 1872, com 7.482; em 1874 com 7.779; em 1879 com 8.893), quando se iniciou seu declínio. Em 1886, havia 8.000 escravos e em 1888, 6.965 .

Inserida num contexto de diversas expectativas sobre a vida em liberdade, a Lei no 3270 , aprovada em $1885^{123}$, conhecida como a Lei Saraiva-Cotegipe ou Lei dos Sexagenários, propunha libertar idosos aos 60 anos de idade, impondo-lhes período de mais cinco anos de trabalho sob tutela senhorial.

Segundo Joseli Mendonça124, a lei dispôs sobre a relação de libertos e ex-senhores buscando preservar os laços de dependência vigentes nas relações de escravidão. A outorga dos sexagenários não pretendia a ruptura da antiga relação entre senhor e escravo.

\footnotetext{
${ }^{121}$ Relatório apresentado à Assembleia Legislativa Provincial do Espirito-Santo pelo presidente da província, desembargador Antonio Joaquim Rodrigues, em 5 de outubro de 1886. Victoria: Typ. do Espirito-Santense, 1886.

122 SALETTO, Nara, Op. Cit., 1996. p. 63.

${ }^{123}$ A Lei dos Sexagenários provocou grande resistência dos senhores de escravos e de seus representantes na Assembleia Nacional. Sobre a análise dos debates e da historiografia sobre o tema cf.: MENDONÇA, Joseli Maria Nunes, Op. Cit., 1995.

${ }^{124}$ Idem, p. 70-79.
} 
Ao contrário, libertando-se esses escravos aos poucos, pretendia-se preservar o gradualismo do processo.

Em 1856, havia na província do Espírito Santo 334 escravos com mais de 60 anos, o equivalente a $2,7 \%$ do total da população cativa ${ }^{125}$. No ano em que foi aprovada a Lei Saraiva-Cotegipe, havia 1.126 escravos entre 60 e 65 anos ${ }^{126}$, ou seja, $8,4 \%$ do total de escravos da província. Nesse universo de sexagenários, mais da metade, $53,3 \%$, residia em Cachoeiro de Itapemirim, 17\% em Itapemirim e 9,2\% em Vitória.

Em nível municipal, observamos, na década de $1850,82,6 \%$ dos escravos em Cachoeiro em idade produtiva. Na década de 1880, diminuíram para 66,6\%.Nosmunicípios deVitóriaeViana,tal proporçãoera de $70,2 \%$ nadécadade 1850 , variandopara $81,2 \%$ nadécadade $1880^{127}$.

Nota-se, por meio das estatísticas, o envelhecimento da população escrava e a dificuldade na década de 1880 em se alimentar a escravidão, inclusive em regiões de maior viabilidade econômica como o município de Cachoeiro, onde os fazendeiros estavam meIhor preparados para renovar a mão de obra nas fazendas.

\section{Conclusão}

Diante do exposto, é possível afirmar que o Espírito Santo, diferentemente de parte da tese da substituição da mão de obra escrava, não sofreu impacto na manutenção da escravidão com a Lei de 1850 . Notou-se, inclusive, crescimento vertiginoso da população escrava no período. Ainda que houvesse outras estratégias para abastecimento de mão de obra cativa na região, a solução para a

125 Dos 12.269 escravos da província, 43,3\% (5.320) tinham até 20 anos; 54\% (6.615) tinham entre 21 e 60 anos e 2,7\% (334) acima de 60 anos. Relatório que o exmo. sr. barão de Itapemirim, primeiro vice-presidente da província do Espírito Santo, apresentou na abertura da Assembleia Legislativa Provincial, no dia 25 de maio de 1857.

${ }^{126}$ Os maiores números são: 600 em Cachoeiro de Itapemirim, 191 em Itapemirim e 104 na capital e Espírito Santo. Os 231 restantes estão divididos em menores números nos demais municípios da província. Relatório apresentado á Assembleia Legislativa Provincial do Espirito-Santo pelo presidente da província, desembargador Antonio Joaquim Rodrigues, em 5 de outubro de 1886. Victoria: Typ. do Espirito-Santense, 1886.

${ }^{127}$ ALMADA, Vilma Aparecida Ferreira de, Op. Cit., 1984. p. 125. 
manutenção da escravidão até 1871 estava na família escrava. Dito de outra forma, a reprodução endógena foi a responsável, em grande medida, pelo alto índice de crescimento dessa população.

Nesse contexto, não surpreende o fato de os fazendeiros, principalmente da região sul, não demonstrarem preocupação com a substituição da mão de obra escrava em suas lavouras. Os núcleos coloniais de imigrantes estrangeiros incentivados pelo governo eram vistos por eles com relativa indiferença. Essa atitude passiva da grande lavoura cafeeira pode ser explicada pelo fato de estar suficientemente abastecida de mão de obra escrava, concentrada primordialmente no sul da província e de seus proprietários estarem seguros da permanência de um sistema tão lucrativo e enraizado na sociedade como o escravista.

A partir de 1871, contudo, através de um processo orientado politicamente, houve a aplicação de leis que afrouxaram pouco a pouco os laços entre senhores e escravos. A análise dos dados apresentados sobre o fundo de emancipação na província revela uma clara relutância dos fazendeiros em efetuar o processo gradual de libertação empreendido pelo governo.

A Lei do Ventre Livre, apesar de não causar um impacto imediato na diminuição da população cativa na província do Espírito Santo, contribuiu significativamente para o colapso da escravatura ao comprometer a última fonte de abastecimento de mão de obra cativa: o ventre das escravas. As liberdades concedidas pelo fundo, em menor grau, a impossibilidade de renovar as escravarias pelo ventre das escravas e o envelhecimento dessa população constituíram o processo gradual de libertação e, em conjunto, foram responsáveis por considerável diminuição do número de cativos da província.

\section{Referências bibliográficas}

Fontes primárias

ARQUIVO PÚBLICO DO ESTADO DO ESPÍRITO SANTO. Ofício enviado aos delegados de Itapemirim e Guarapari e subdelegados de Benevente. 1851. Série Accioli, livro 66 (manuscritos).

CÚRIA METROPOLITANA DE VITÓRIA. Livro de batismo de escravos da Ca- 
tedral. L.04B, 1859-1872.

. Livro de batismo de filhos de escravos que nasceram depois da lei de 1871. L.05B, 1871-1887.

DAEMON, Basílio Carvalho. Província do Espírito Santo: sua descoberta, história cronológica, sinopse e estatística (1879). Vitória: Secretaria do Estado da Cultura; Arquivo Público do Estado do Espírito Santo, 2010.

ESPÍRITO SANTO (Estado). Presidentes de província (1833-1888). Relatórios de presidentes da província do Espírito Santo.

\section{Fontes secundárias}

ALMADA, Vilma Paraíso Ferreira de. Escravismo e transição: o Espírito Santo, 1850/1888. Rio de Janeiro: Edições Graal, 1984.

BAPTIST, Edward E. A segunda escravidão e a Primeira República americana. Almanack. Guarulhos, n. 05, p. 5-41, 1º semestre de 2013.

BITTENCOURT, Gabriel Augusto de Mello. Café e modernização: o Espírito Santo no século XIX. Rio de Janeiro: Liv. Ed. Cátedra, 1987.

BRITO, Fausto. Crescimento demográfico e migrações na transição para o trabalho assalariado no Brasil. Revista Brasileira de Estudos de População. Campinas, vol. 21, n. 1, p. 5-20, jan./jun. 2004.

CAMPOS, Adriana Pereira. Nas barras dos tribunais: Direito e escravidão no Espírito Santo do século XIX. Programa de Pós-graduação stricto sensu em História da UFRJ, 2003.

. Prescrição da escravidão e a "liberdade oprimida" no Brasil dos Oitocentos. Revista de História (São Paulo), vol. 34, n. 2, p. 206-220, jul./dez. 2015.

CARVALHO, Enaile Flauzina. Redes mercantis: a participação do Espírito Santo no complexo econômico colonial de 1790-1821. Vitória: Secult, 2010.

CONDE, Bruno Santos. Depois dos jesuítas: a economia colonial do Espírito Santo (1750-1800). Dissertação (Mestrado em História). Universidade Federal do Espírito Santo, Vitória, 2011.

CONRAD, Robert. Os últimos anos da escravatura no Brasil: 1850-1888. Rio de Janeiro: Civilização Brasileira; 1975.

COSTA, Emilia Viotti da. Da monarquia à república: momentos decisivos, $5^{\mathrm{a}}$ ed. São Paulo: Brasiliense, 1989.

COSTA, Michel Dal Col. Guerra internacional e batalhas do cotidiano: a 
comarca de Vitória/ES no programa imperial de extinção gradual da escravidão. In: SEMINÁRIO INTERNACIONAL BRASIL NO SÉCULO XIX. Niterói, 2015. Anais do Seminário Internacional Brasil no Século XIX. p. 1-19. Niterói: Sociedade de Estudos dos Oitocentos. SEO, 2015. Disponível em: http://www.seo.uff.br/images/Anais/Arthur/Michel\%20 Dal\%20Col.pdf.

DAUWE, Fabiano. A libertação gradual e a saída viável. Os múltiplos sentidos da liberdade pelo fundo de emancipação de escravos. Dissertação (Mestrado), UFF, Niterói, 2004.

. Liberdade inconveniente: os múltiplos sentidos da liberdade pelo fundo de emancipação de escravos. In: X ENCONTRO ESTADUAL DE HISTÓRIA, UFSM, 2010. Anais do X Encontro Estadual de História: O Brasil no Sul: cruzando fronteiras entre o regional e o nacional. UFSM, 2010. Disponível em: http://www.eeh2010.anpuh-rs.org.br/site/anaiscomplementares. Acesso em: 05/01/2016.

FLORENTINO, Manolo. Em costas negras: uma história do tráfico de escravos entre a África e o Rio de Janeiro: séculos XVIII e XIX. São Paulo: Companhia das Letras, 1997.

FURTADO, Celso. Formação econômica do Brasil. Edição comemorativa. São Paulo: Companhia das Letras, 2009.

HASENBALG, Carlos Alfredo. Discriminação e desigualdades raciais no Brasil. Rio de Janeiro: Graal, 1979.

MACHADO, Cacilda; FLORENTINO, Manolo. Famílias e mercado: tipologias parentais de acordo ao grau de afastamento do mercado de cativos: século XIX. Afro-Ásia, n 24, 2000.

MAMIGONIAN, Beatriz; SIRQUEIRA, Ana Paula Pruner de. A campanha abolicionista e a escravidão no século XIX no Brasil, em Cuba e nos Estados Unidos. In: CAMPOS, Adriana Pereira; SILVA, Gilvan Ventura da(org.).Aescravidãoatlântica:dodomíniosobreaÁfricaaosmovimentos abolicionistas. Vitória: Editora GM, 2011.

MARQUESE,RafaeldeBivar.Senhoresdocorpo,missionáriosdamente:senhores, letrados e o controle dos escravos nas Américas, 1660-1860. São Paulo: Companhia das Letras, 2004.

MENDONÇA,JoseliMariaNunes.Aleide1885eoscaminhosdaliberdade.Dissertação (Mestrado). Universidade Estadual de Campinas, Campinas, 1995.

MERLO, Patrícia Maria da Silva. O nó e o ninho: estudo sobre a família escrava em Vitória, Espírito Santo, 1800-1871. Tese (Doutorado em História). UFRJ, Rio de Janeiro, 2008.

RIBEIRO, Geisa Lourenço. Enlaces e desenlaces: família escrava e reprodução 
endógena no Espírito Santo (1790-1871).Dissertação (Mestrado em História). Ufes, Vitória, 2012.

SALETTO, Nara. Transição para o trabalho livre e pequena propriedade no Espírito Santo (1888-1930). Vitória: Edufes, 1996.

SCOTT, Rebecca J.Emancipação escrava em Cuba: a transição para o trabalho livre, 1860-1899. Rio de Janeiro: Paz e Terra; Campinas: Unicamp, 1991.

SIMONATO, Juliana Sabino. Fazenda Santa Helena: escravidão, bastardia e poder. Vitória: IHGES, 2013.

SKIDMORE, Thomas E. Preto no branco: raça e nacionalidade no pensamento brasileiro (1870-1930). São Paulo: Companhia das Letras, 2012.

SLENES, Robert. Senhores e subalternos no oeste paulista. In: ALENCASTRO, Luiz Felipe de. História da vida privada. São Paulo: Companhia das letras, 1997, vol. 2.

TOMICH, Dale W. Pelo prisma da escravidão: trabalho, capital e economia mundial. São Paulo: Edusp, 2011.

Recebido em: 17/09/2017 - Aprovado em: 04/07/2018 